\title{
Continental Rift Setting for the Central Part of the Mexican Volcanic Belt: A Statistical Approach
}

\author{
Surendra P. Verma*
}

\author{
Centro de Investigación en Energía, Universidad Nacional Autónoma de México, Priv. Xochicalco s/no., Col. Centro, \\ Temixco, Mor. 62580, México
}

\begin{abstract}
I prepared compilations of geochemical data from the central part of the Mexican Volcanic Belt (C-MVB), the Central American Volcanic Arc (CAVA) from Guatemala to northwestern Costa Rica, the continental arc of the Andes in South America, other mostly island arcs, extensional and continental break-up regions, and continental rifts. Using quantitative statistical methods, the origin of the C-MVB is constrained as a continental rift. Specifically, this continental rift setting for the C-MVB is inferred from conventional bivariate discrimination diagrams, new natural logarithmtransformed correct statistics-based discriminant function diagrams, quantitative $\mathrm{Nb} / \mathrm{Nb} *$ parameter, and $99 \%$ confidence limits of the mean for the ratios of slab- or continental crust-sensitive and mantle-sensitive parameters. The subductionrelated models based on qualitative interpretations most commonly proposed for the Mexican Volcanic Belt in the literature are not supported from these robust quantitative constraints. All geological, structural, geochemical, isotopic (Sr, Nd, $\mathrm{Pb}, \mathrm{Os}$, and $\mathrm{Be}$ ), and geophysical data are in fact consistent with this statistics-based conclusion of the continental rift setting and exclude involvement of the subducted slab from the genesis of the C-MVB magmas.
\end{abstract}

Keywords: subduction, rift, extension, statistics, geochemistry, Mexico.

\section{INTRODUCTION}

The Cocos (oceanic) plate (Fig. 1) has been subducting in southern Mexico beneath the North American plate along the north-western part of the Middle America Trench (MAT) and in Central America (conventionally from Guatemala to northwestern Costa Rica) beneath the Caribbean plate along the south-eastern part of the MAT [1-5]. This results in a complex tectonics with a triple junction forming at the middle part of the more than $2000 \mathrm{~km}$ long subduction zone.

A volumetrically important volcanic province in southern Mexico is the Mexican Volcanic Belt (MVB) that has also been proposed to be classified as a large igneous province [6]. The MVB (Fig. 1) is a roughly east-west structure of Miocene to Recent age, 20-150 km-broad, about $1000 \mathrm{~km}$ long, which extends from near Puerto Vallarta at the Pacific coast to near Veracruz at the Gulf of Mexico coast and houses around 8000 volcanoes [7-9]. Its smaller western part corresponds to the subduction of a small oceanic plate (called Rivera plate; located at the NW of the area covered in Fig. (1)), whereas the major west-central to eastern parts correspond to the Cocos plate.

In Central America, the main volcanic province is the Central American Volcanic Arc (CAVA; Fig. 1). For this arc from Guatemala to northwestern Costa Rica, the subduction process of the Cocos plate beneath the Caribbean plate $[1,4]$ seems to be a standard textbook type example, where a welldeveloped fore-arc basin is present, the Wadati-Benioff zone beneath the CAVA is between 100 and $200 \mathrm{~km}$ deep, and the CAVA is oriented sub-parallel to the Middle-America

*Address correspondence to this author at the Centro de Investigación en Energía, UNAM, Priv. Xochicalco s/no., Col. Centro, Temixco, Mor.62580,Mexico; Email: spv@cie.unam.mx
Trench (see CAVA and MAT in Fig. (1)). The origin of this province extending from Guatemala to northwestern Costa Rica has thus been attributed to this subduction process [1012]. Between these two major provinces only the Los Tuxtlas Volcanic Field (LTVF; Fig. 1) and some isolated volcanoes such as El Chichón and Volcán Tacaná exist in southern Mexico [5]. I will not consider the origin and evolution of the LTVF because they have been discussed elsewhere $[5,13]$ and attributed solely to the ongoing extensional processes.

Although there is a consensus that the origin of the Guatemala to northwestern Costa Rica part of the CAVA is related to the subduction process [10-12], the origin of the MVB has been largely controversial [5], and a plethora of models have been proposed that vary from simple subduction relationship of the Cocos plate beneath the North American plate [7, 14-19], to the action of a mantle plume $[20,21]$, to the ongoing rifting processes within the MVB [5, $22-32]$, and to hybrid or more complex tectonic models [3336]. Therefore, given the complexity of the MVB more constraints are still required to eventually solve this controversy.

In order to throw further light on this complex tectonomagmatic problem, I selected a well-studied area comprising $98.5^{\circ} \mathrm{W}-100.5^{\circ} \mathrm{W}$ longitudes and $18.5^{\circ} \mathrm{N}-21.0^{\circ} \mathrm{N}$ latitudes from the central part of the MVB (see the rectangle marked "Fig. (3)" in Fig. (1). This selection was based on the criteria that this region has been considered a key area to understand the possible relationships between the Cocos and North American plates and should not have any possible influence from the Rivera plate.

I used the following approach:

i. Compile all available geochemical data from this area of the MVB (called C-MVB in this work). Similarly, 


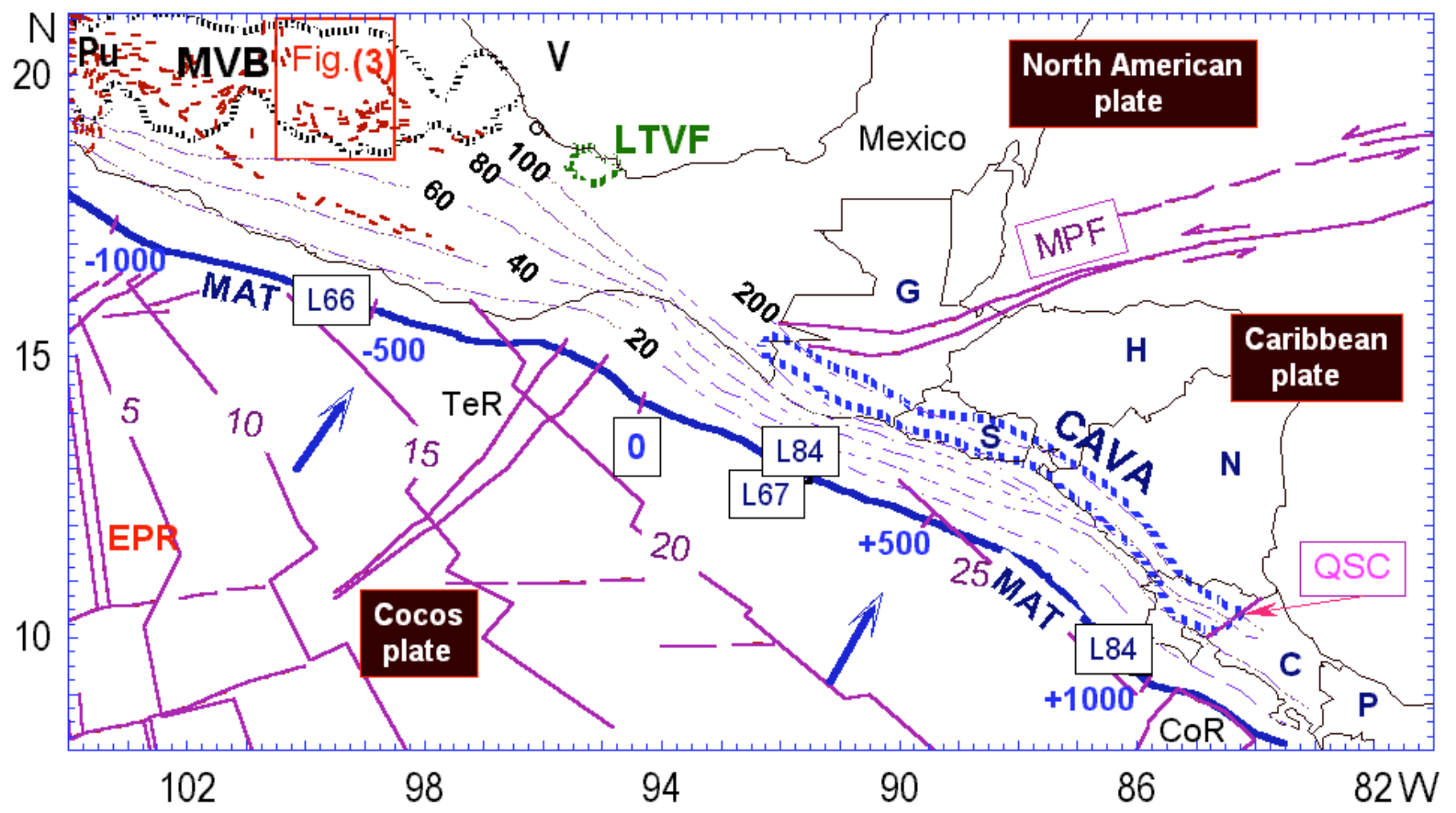

Fig. (1). Simplified regional tectonics of southern Mexico and Central America showing the approximate location of the Mexican Volcanic Belt (MVB), Los Tuxtlas Volcanic Field (LTVF), and Central American Volcanic Arc (CAVA), map modified after [5]. The box marked Fig. (3) is the study area of the Central Mexican Volcanic Belt (C-MVB). The location of the Middle America Trench (MAT) is shown by thick blue curve. Other tectonic features are: EPR-East Pacific Rise; TeR-Tehuantepec Ridge; CoR-Cocos Ridge; MPF-Motagua-Polochic fault system; and QSC-Quesada sharp contortion. L66, L67, and L84 are the Deep Sea Drilling Project Legs, during which sediment and basalt samples were recovered from the ocean floor. The countries are: G-Guatemala; S-El Salvador; H-Honduras; N-Nicaragua; C-Costa Rica; P-Panamá. The cities are: Pu-Puerto Vallarta; and V-Veracruz. The traces marked by numbers 5 to 25 on the oceanic Cocos plate give the approximate age of the plate; the dashed-dotted lines marked by numbers 20 to 200 on the continental (North American and Caribbean) plates indicate the approximate depth of the subducted Cocos plate (note the absence of deeper than $60 \mathrm{~km}$ depth contour in the study area marked Fig. (3); even the $60 \mathrm{~km}$ depth contour lies south of the volcanic front); the numbers $-1000,-500,0,+500$, and $+1000 \mathrm{represent}$ the approximate horizontal distance in $\mathrm{km}$ from the triple junction represented by the intersection of three plates (Cocos, North America, and Caribbean); the negative numbers are for Mexico whereas the positive numbers are for Central America. Simplified fracture and fault main patterns are also shown schematically using red dashed curves.

establish representative databases for the CAVA, the Andes from South America, other arcs including all those that surround the Pacific Ocean, extensionrelated and continental break-up regions, and continental rifts.

ii. Use a few conventional bivariate discrimination diagrams most frequently used in the literature and test their functioning from data from two continental arcs (CAVA and Andes) and all compiled island arcs before their use for the C-MVB.

iii. Examine the C-MVB data from new, recent statisticsbased discriminant function tectonomagmatic discrimination diagrams whose correct functioning was already tested by the original authors using training sets and data from diverse geological areas around the world.

iv. Apply a new methodology of quantitatively interpreting from all databases the $\mathrm{Nb}$-anomaly in extensively used multi-element normalized diagrams.

v. Using ratios of slab- or continental crust-sensitive (such as alkali and alkaline earth elements; e.g., enrichment in $\mathrm{K}$ and $\mathrm{Ba}$ ) and mantle-sensitive (rareearth and high-field strength elements; e.g., enrich- ment in $\mathrm{La}$ and $\mathrm{Ce}$, or in $\mathrm{Nb}$ and $\mathrm{Zr}$; enrichment in rare-earth elements might also sometimes come from felsic continental crust) parameters $[5,12,13]$, carry out quantitative comparisons of $99 \%$ confidence limits of the mean for the C-MVB with the CAVA, Andes, island arcs, extension-related and continental break-up regions, and continental rifts. The comparison of the C-MVB with the CAVA is particularly meaningful because the latter has originated from the subduction of the same oceanic plate (Cocos plate; Fig. 1). If the C-MVB has also resulted exclusively or largely from the same subduction process, its geochemistry should be similar to that of the CAVA. The Andes is another well known continental arc, and the comparison is likely to shed new light on this problem. Similarly, this quantitative comparison of the CMVB magmas with other island arcs and extensional or rifted areas would also be meaningful.

vi. Finally, point out implications of other geological, geochemical, and geophysical studies carried out in the MVB.

The proposed methodology avoids the purely qualitative graphical analysis hitherto practiced by most geologists and geochemists - an approach likely to yield subjective results. 
The new quantitative approach is objective, robust, reproducible, and statistically valid. For this reason, I have refrained from showing numerous conventional bivariate, ternary or multi-element diagrams (most of them have been used for qualitative, subjective interpretations); instead, this new statistical approach is followed in this work through the presentation of innovated tabulated information and diagrams in geological sciences.

\section{DATABASES}

Six databases were established for: (1) C-MVB; (2) CAVA; (3) Andes; (4) Island arcs; (5) Extension-related and continental break-up regions; and (6) Continental rifts.

For the C-MVB database, all published analyses in the selected area were compiled. For the sake of quantitative interpretation, this area was divided into two regions by arbitrarily setting a geographical limit for nearer to and farther away from the MAT. The prominent volcanic areas and structures corresponding to nearer the MAT (as arranged from west to east and from nearer to and farther from the MAT) were: Zitácuaro-Valle de Bravo [37-40]; Volcán Nevado de Toluca [41-43]; Tenango Volcanic Field [43, 44]; Sierra de Chichinautzin and nearby areas [19, 26, 29, 43, 4556]; Valle de México [44, 45, 57]; Sierra Nevada and Río Frío [45, 52, 57]; Volcán Popocatépetl [45, 57-63]; and Volcán Iztaccíhuatl $[45,49,52]$. Similarly, the samples from areas farther from the MAT were taken from: Caldera de Amealco [64, 65]; Volcán Zamorano [66]; Querétaro [5, 67, 68]; Huichapan [69]; Tizayuca Volcanic Field [70]; Meseta Río San Juan [71]; State of Hidalgo [68]; and Apan Volcanic Field [72].

For the CAVA database, data were first downloaded from M. J. Carr's website (accessed on April 30, 2005) $\mathrm{http}: / / \mathrm{www} . \mathrm{rci}$.rutgers.edu/ carr, and were later complemented by data from more recent published papers [73-76]. For the Andes database, geochemical data were compiled from numerous papers [77-104]. For both arcs (CAVA and Andes), the compiled data were divided into two parts: the volcanic front region (called CAVA(f) and Andes(f), respectively) and back-arc region (called CAVA(b) and Andes(b), respectively).

For island arcs, extensional and break-up regions, and continental rifts, the databases were the same as those used by me in an earlier publication [13]. The arcs, from which data were compiled, were: Aegean, Alaska Peninsula, Aleutian, Barren Island, Bicol, Burma, Fiji, Isu-Bonin, Japan, Java, Kamchatka, Kermadec, Kurile, Lesser Antilles, Luzon, Mariana, New Britain, New Hebrides, Papua-New Guinea, Philippines, Ryukyu, Sangihe, Scotia, South Shetland, Sua, Sunda-Banda, Taupo volcanic zone, Tonga, TongaKermadec, and Vanuatu. The extensional and continental break-up regions were: Beppu-Shimabara graben (Japan), Central European Volcanic Province (Germany), Chifeng (N China), Henry Basin (USA), and Mali and Morocco (NW Africa). Similarly, the continental rifts were: Abu Gabra, Africa (East, NW, W), Anatolia (Western), Antarctica, Basin and Range, China (E, NE, SE), Colorado Plateau Transitional to Basin and Range, Ethiopia, Kenya, Massif Central, Rio Grande, San Quintin Volcanic Field, Saudi Arabia, Shombole volcano, Silali volcano, Spain (SE), Taiwan (NW), Taiwan Strait, Turkey, Uganda (SW), and USA (W).

\section{RESULTS}

The samples compiled in the C-MVB database were plotted on the conventional TAS diagram $[105,106]$. The major-element data were first adjusted to $100 \%$ on an anhydrous basis using the SINCLAS computer program [107, 108], and Fe-ratio adjustment was done using the Middlemost option [109] in SINCLAS. Then, the resulting total alkalis and silica values for each sample were plotted in the TAS diagram after choosing the appropriate symbols depending on the rock classification from SINCLAS. Different types of rocks have erupted in the C-MVB (Fig. 2) that vary from sub-alkaline to alkaline and from basic (basaltic) to acid (rhyolitic) varieties (see Fig. (3) for locations of samples and the approximate trace of the C-MVB). In this context, it is important to mention that many researchers do not strictly follow the recommendations of the International Union of Geological Sciences (IUGS) for volcanic rock nomenclature even if they use the TAS diagram for classification because the Fe-ratio has to be adjusted according to some selected criteria before recalculating the analyses at $100 \%$ anhydrous basis [105-109]. Here, I strictly followed the IUGS recommendations as shown above.

The samples from the study area of the rectangle (Fig. 1) delimited by $98.5^{\circ} \mathrm{W}-100.5^{\circ} \mathrm{W}$ longitudes and $18.5^{\circ} \mathrm{N}-$ $21.0^{\circ} \mathrm{N}$ latitudes (C-MVB), for which location coordinates were provided or could be estimated from the geologic maps in the original articles, are plotted in Fig. (3). Both alkaline and sub-alkaline varieties of rocks have erupted throughout the C-MVB, irrespective of the distance from the MAT. Note that numerous samples with the description of their sampling locations but with no possibility of estimating their approximate coordinates could not be plotted in Fig. (3).

For the sake of interpretation and quantitative comparisons, the study area was divided into two zones of approximately the same width: close to the MAT (CMVB(f) - the frontal or nearer part of the C-MVB); and far from the MAT $(\mathrm{CMVB}(\mathrm{b})-$ the back or farther part of the C-MVB). The corresponding approximate limit of this division is shown in Fig. (3).

Note also that the CMVB(b) is much less studied than the CMVB(f). When the MVB will be better studied in future, the kind of work presented in this paper can be repeated to obtain new inferences from the application of quantitative statistical methodology. Nevertheless, a greater number of samples are not likely to change the major conclusion reached in the present paper; in fact, the conclusion is likely to be valid at a more strict confidence level. Another improvement in statistical analysis can also be incorporated in future when complete geochemical data will be reported on radiometrically dated samples. The current practice is to report age data on a much smaller set of samples than the geochemical data from a given area, or report either only the age data or the geochemical information. With the availability of complete geochemical and geochronological data, one can apply these statistical principles to study the geochemical evolution both in space and time, and not just in space as done here.

\section{DISCUSSION}

If we were dealing with the individual samples, the laboratory variance (analytical errors) would be important to 


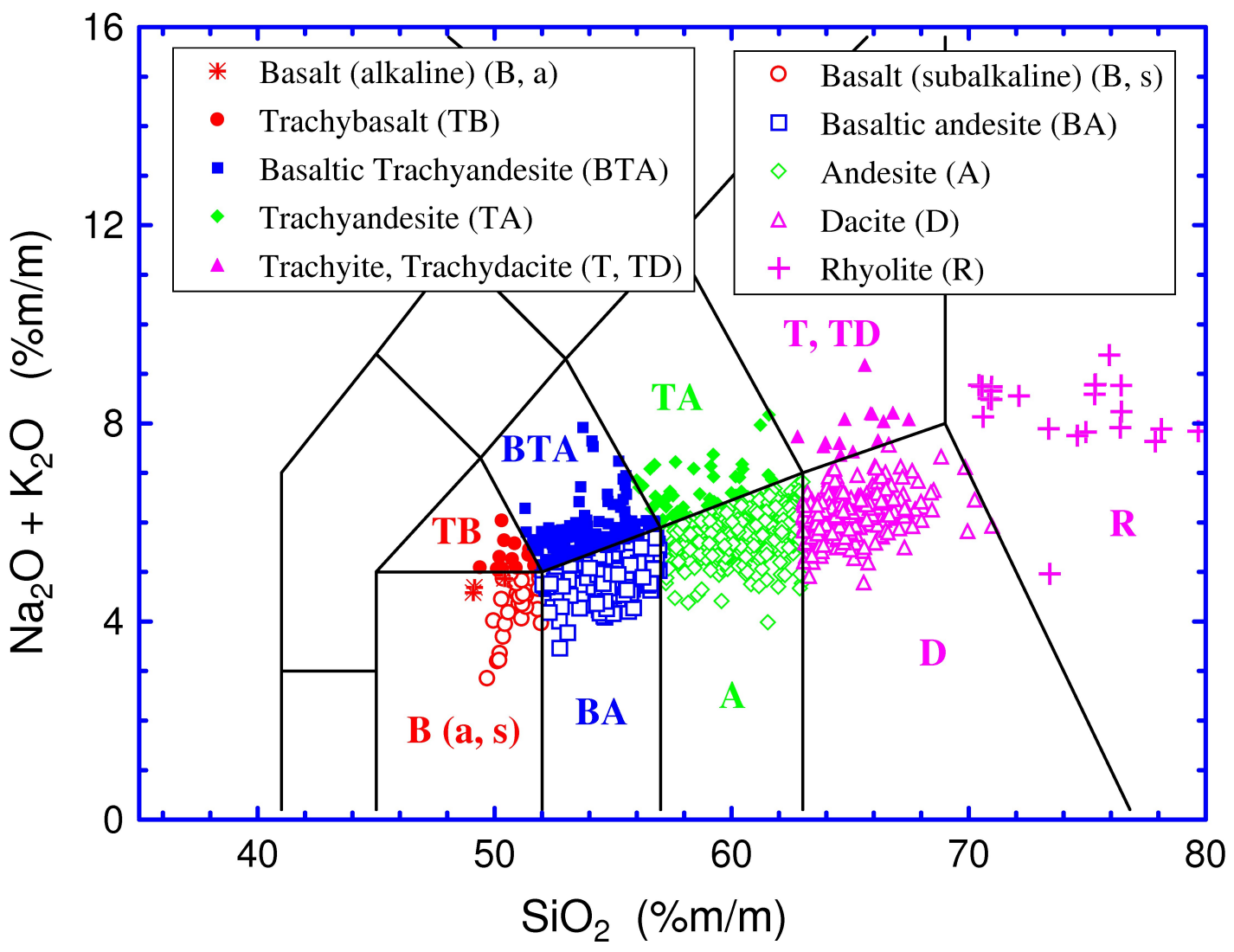

Fig. (2). Conventional Total Alkalis versus Silica (TAS) diagram for the classification of compiled rocks from the Central Mexican Volcanic Belt (C-MVB) using the SINCLAS computer program [107]. All symbols are explained as insets and the rock types are as inferred from [107].

estimate and propagate, although it is a difficult task because of covariance terms that have to be taken into account. Furthermore, analytical errors cannot be easily represented in discrimination diagrams, e.g., Fig. (4), because they are generally heteroscedastic and therefore error bars would be of different sizes at different parts of such diagrams. Nevertheless, in a collective interpretation of a set of samples from a given area or tectonic setting, the spread of the data on this set of samples gives an estimate of the total uncertainties, i.e., both laboratory and field variances are automatically combined, although we cannot assign them individually to each sample. It is therefore worthwhile to mention that the analytical errors on individual samples (seldom reported by the original authors) are automatically taken into account. The calculation of the $95 \%$ or $99 \%$ confidence limits of the mean not only takes these field and laboratory uncertainties into account but also incorporates the limited nature of the sampling (sample sizes) in terms of the Student t parameter. Thus, the interpretation based on confidence intervals is a good approach to draw statistically sound conclusions.

\section{Conventional Discrimination Diagrams}

A number of bivariate diagrams have been proposed in the literature to discriminate magmas from different tectonic settings [55, 110-116]. A more detailed evaluation of most existing discrimination diagrams has recently been carried out by [117], which shows that most simple bivariate and ternary diagrams do not properly work, or contain too few tectonic settings to be of much use in modern tectonomagmatic interpretations and that the new discriminant function diagrams (proposed during 2004-2009) are recommended to be used in future.

Four selected conventional discrimination diagrams are presented in Fig. (4). Functioning of these diagrams was tested from the databases of the CAVA, Andes and several island arcs. The diagrams seem to work for discriminating island arc magmas. However, continental arc magmas (from both the CAVA and Andes), tend to show more dispersion on all of these conventional bivariate diagrams.

The C-MVB samples, however, mostly plot in the within-plate (Fig. 4A, C, D) or MORB + OIB fields (Fig. 4B), irrespective of whether they come from nearer to or farther from the MAT. Therefore, all C-MVB basic magmas according to these bivariate diagrams define a within-plate affinity.

I, however, stress that the Ti-V diagram [112] does not explicitly contain within-plate setting (Fig. 4C). This binary diagram was tested to work somewhat poorly for arc magmas, and was therefore modified by [55]. This modified Ti-V discrimination diagram [55] contains the tectonic settings of island arc, continental rift, and ocean-island basalts, in which 


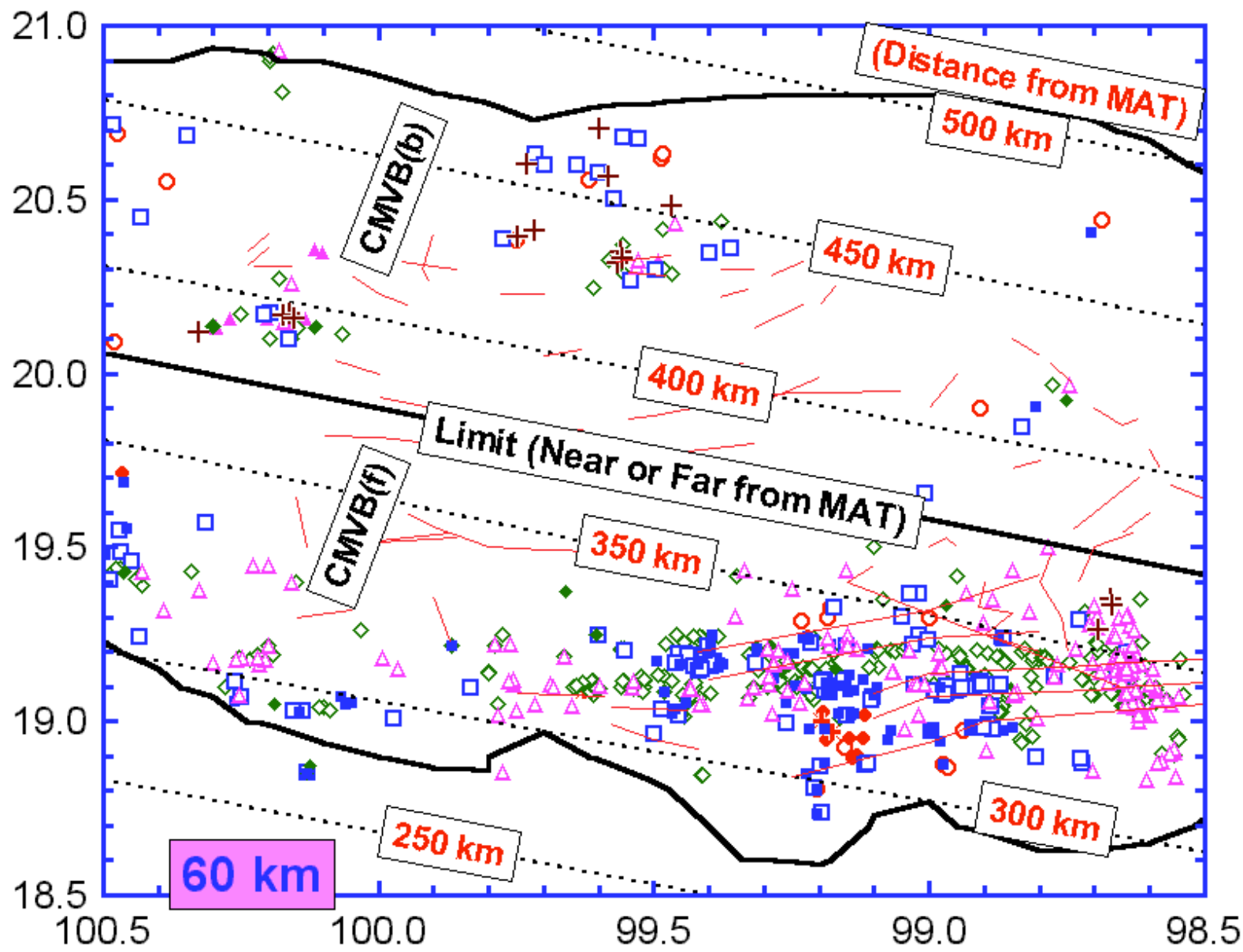

Fig. (3). Geographical distribution of geochemically analyzed samples with location coordinates that were either reported or were inferred from the location maps. Note $60 \mathrm{~km}$ refers to the approximate depth of the subducting Cocos plate at the lower part of the diagram and lies at about $230 \mathrm{~km}$ horizontal distance from the Middle America Trench (MAT; see Fig. (1) for more information). Dotted lines marked $250 \mathrm{~km}$ to $500 \mathrm{~km}$, show the approximate horizontal distance from the MAT. An arbitrarily set limit characterizes the samples as: Near to -CMVB(f) and Far-CMVB(b) from the MAT. Open symbols were used for subalkaline rocks whereas filled symbols were for alkaline rocks (for details on symbols, see Fig. (2)). Note both alkaline and subalkaline rock types occur throughout the C-MVB. Main fracture and fault patterns are also shown schematically using red dashed curves.

the C-MVB samples plot in the continental rift field or in the overlap region of continental rift with ocean-island. I clarify, however, that the approximate eye-fitted boundaries proposed by [55] are not included in Fig. (4C).

\section{Ternary Discrimination Diagrams}

Other commonly used discrimination diagrams fall in the category of ternary diagrams [118-121]. Such diagrams were not used in this work for three reasons: (i) functioning of some of these diagrams was tested by [55], which seemed to require new field boundaries; (ii) experimental errors in ternary diagrams are modified and therefore such diagrams are less appropriate [122-124]; and (iii) these diagrams generally do not work properly [117].

\section{New Discriminant Function Discrimination Diagrams}

Instead of these conventional bivariate and ternary diagrams, recently (2004-2009) there has been a renewed interest in the proposal of new multi-element diagrams based on correct statistical methodology [125-128]. In fact, the conventional bivariate or ternary diagrams were characterized by the following problems common to all of them [127, 128]: (a) the field-boundaries were obtained by a subjective method of fitting lines by eye; (b) the implications of "constant-sum" constraint of geochemical data were ignored; and (c) the samples used in creating these diagrams perhaps were not statistically representative. All of these problems were overcome by the new multi-element diagrams [126-128]. For more information on this statistical methodology, the reader can also refer to the following references [129-135].

These new correct statistics-based, discriminant function, natural log-ratio transformed diagrams $[126,128]$ were extensively tested by the original authors using testing sets and other data from all around the world and from all four tectonic settings (arc, rift, ocean-island, and mid-ocean ridge). Some of these diagrams were also evaluated by [136] using both fresh and altered rocks and by [117] using an extensive updated worldwide database.

I therefore used these new diagrams without further testing, to decipher the dominant tectonic setting of the C-MVB and the results are presented in Fig. (5) for major-elements and Fig. (6) for trace-elements. All diagrams clearly suggest a continental rift setting for the C-MVB, because very high 

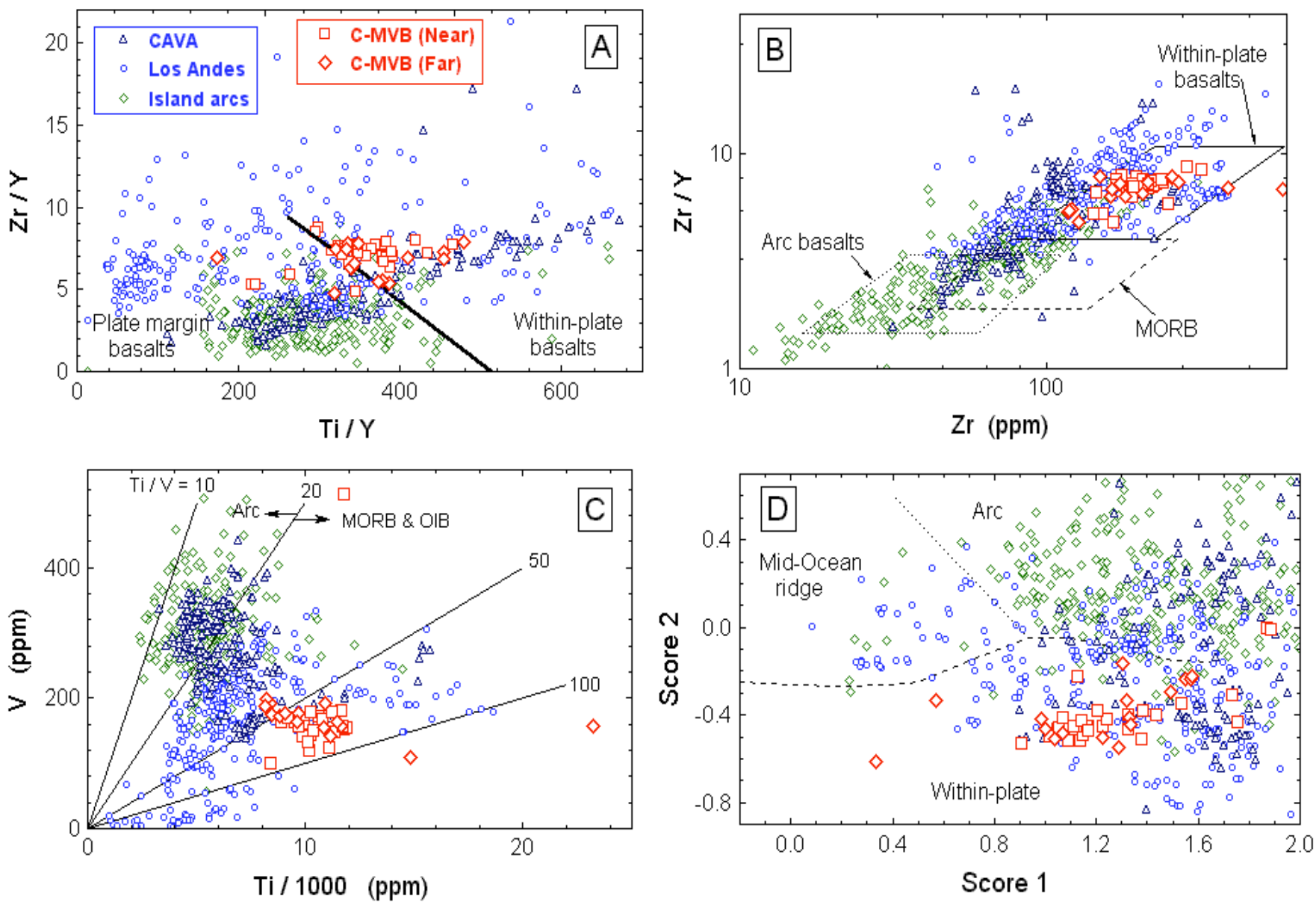

Fig. (4). Binary discrimination diagrams for the C-MVB basic rocks. Note all diagrams indicate a "within-plate" ("continental rift") setting for the C-MVB. (a) Ti/Y-Zr/Y [110]; (b) Zr-Zr/Y [111]; (c) Ti-V [112]; and (d) Score 1-Score 2 [114].

percentages of C-MVB basic rock samples from both nearer to and farther from the MAT plot in this field. The geochemistry of the C-MVB basic magmas is certainly not consistent with an arc setting because practically no samples plot in the arc field. The more important is the fact that there is no distinction between magmas from nearer and farther from the trench.

The discrimination boundaries in these diagrams [125128] are probability based. A sample plotting right at boundary separating two tectonic fields has $50 \%$ (or 0.50 ) probability to belong to either tectonic setting, but as we move towards the interior of a tectonic field, the probability for that particular field increases and for the other field decreases so that the total probability is $100 \%$. In a paper currently under preparation on new discrimination diagrams based on log-ratio transformation of immobile elements ( $\mathrm{Ti}$, $\mathrm{V}, \mathrm{Y}, \mathrm{Nb}$, and $\mathrm{Zr}$ ), Verma and Agrawal have shown that the iso-probability contours of $70 \%$ and $90 \%$ are very close to the discrimination boundaries (for distances similar to the size of the symbols) and consequently, the probability to belong to the other tectonic field rapidly decreases to $30 \%$ and $10 \%$, respectively (plots cannot be shown here because the work by these two authors is still unpublished).

New work on such discriminant function diagrams for intermediate magmas is currently under progress, which should enable us in future to use them for the study of areas such as the MVB with a complex tectonic setting.

\section{Quantitative Interpretation of Nb-Anomaly in Multi- Element Normalized Diagrams}

When the so called fast analytical techniques such as flame photometry, atomic absorption spectrometry, colorimetry and optical emission spectrometry, and later the more sophisticated instrumental methods such as neutron activation analysis, x-ray fluorescence spectrometry and mass spectrometry, became available, the bivariate and ternary diagrams were insufficient to handle the abundant geochemical data of a large number of chemical elements, and new graphical methods of multi-element diagrams involving several (more than three) elements in a single diagram were developed. A plethora of such multi-element diagrams have come into existence [137], all of which rely on the normalization with respect to "accepted" average values (Table 1) of a common planetary or earth material such as average chondrite, MORB, or primitive mantle, among others [138-142]. Bulk silicate earth values [142] also summarized in Table 1, are useful for normalization purposes to decipher the behavior of different groups of elements [143], such as large ion lithophile elements (LILE), light rare-earth elements (REE) and high field strength elements (HFSE). An innovative handling of such new parameters provided additional con- 

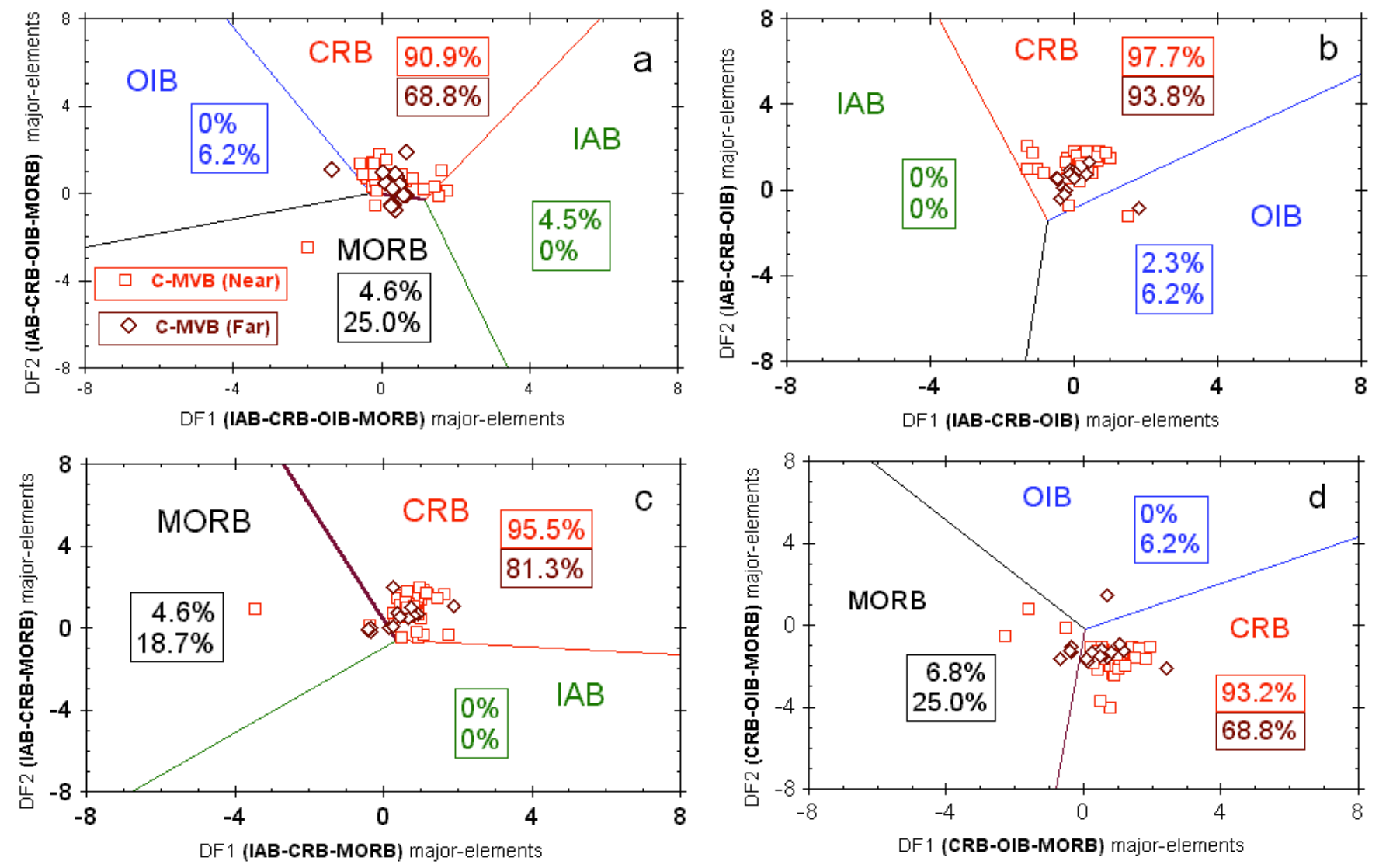

Fig. (5). Four discriminant function diagrams based on natural log-ratio transformation of major-element ratios in basic rocks from the CMVB [126]. The percentage values given next to the tectonic setting names represent the \% success obtained for the C-MVB samples; the first number (listed in the upper part) is for the samples nearer to the MAT and the second number is for those farther from the MAT. The symbols used are shown as inset in Fig. (5A). Note a CRB setting is clearly discernible from all diagrams. (A) Four tectonic settings IABCRB-OIB-MORB (Arc-Continental rift-Ocean Island-Mid-Ocean ridge). (B) Three tectonic settings IAB-CRB-OIB. (C) Three tectonic settings IAB-CRB-MORB. (D) Three tectonic settings CRB-OIB-MORB.

straints to support an extension-related origin of the Los Tuxtlas volcanic field in southern Mexico [13].

It is a common practice to present lanthanide or REE data as a chondrite-normalized plot. Similarly, for a combination of these and other elements MORB- or primitive mantlenormalized plots have been used. The $\mathrm{Nb}$-anomaly as qualitatively observed in such plots for different types of igneous rocks, has been commonly interpreted to indicate tectonic provenance. Specifically, the presence of a negative $\mathrm{Nb}$ anomaly has been taken as evidence for an arc setting and its absence as a rift or OIB setting. However, quantitative interpretation of the $\mathrm{Nb}$-anomaly has been rather scarce [13]. I attempted such a quantitative approach to interpret these multi-element diagrams.

For quantitatively interpreting a primitive mantlenormalized multi-element diagram (see the "Primitive Mantle" column in Table 1), one should first examine the sequence of elements in the first part of such a multi-element diagram which contains $\mathrm{Nb}$. The first three elements $\mathrm{Cs}, \mathrm{Rb}$, and $\mathrm{Ba}$ are LILE; these are followed by four HFSE Th, U, $\mathrm{Nb}$, and $\mathrm{Ta}$, which in turn are sequenced by a LILE $\mathrm{K}$ and a light-REE La, and so on. The $\mathrm{Nb}$-anomaly can be quantitatively defined with respect to the nearest LILE $\mathrm{Ba}$ on one side and the nearest light-REE La on the other as:

$$
\left\{\mathrm{Nb} / \mathrm{Nb}^{*}\right\}_{\mathrm{pm}}=\frac{2 \cdot\left(\mathrm{Nb}_{\mathrm{sa}} / \mathrm{Nb}_{\mathrm{pm}}\right)}{\left(\mathrm{Ba}_{\mathrm{sa}} / \mathrm{Ba}_{\mathrm{pm}}\right)+\left(\mathrm{La}_{\mathrm{sa}} / \mathrm{La}_{\mathrm{pm}}\right)}
$$

where the element symbols $\mathrm{Nb}, \mathrm{Ba}$, and $\mathrm{La}$ refer to the concentrations of these elements in a sample or normalizing material; the subscript sa stands for the sample and $\mathrm{pm}$ for the primitive mantle; the superscript $*$ refers to the $\mathrm{Nb}$ concentration that would result from a smooth pattern for $\mathrm{Ba}$ to La on the primitive mantle-normalized multi-element diagram (see Fig. (4) in [13] for an example of such diagrams). Note that on each side of $\mathrm{Nb}$, the elements $\mathrm{Ba}$ and $\mathrm{La}$ are exactly the third nearest neighbors, i.e., at the same distance on both sides in the multi-element diagram. This observation makes the simple equation (1) applicable for the calculation of this quantitative parameter.

Note that the reference elements $\mathrm{Ba}$ and La were selected to calculate the $\mathrm{Nb}$-anomaly particularly because: (i) I wanted to have a large number of results from a given area (both $\mathrm{Ba}$ and $\mathrm{La}$ are generally analyzed when $\mathrm{Nb}$ is reported for a given sample); (ii) the data for the neighbor elements Th, U and Ta were less common; (iii) these neighbor elements (Th, U, and Ta) belong to the same geochemical group (HFSE) as $\mathrm{Nb}$, therefore $\mathrm{Nb}$-anomaly would have little meaning; and (iv) one should be referring to $\mathrm{Nb}$ (a HFSE) 

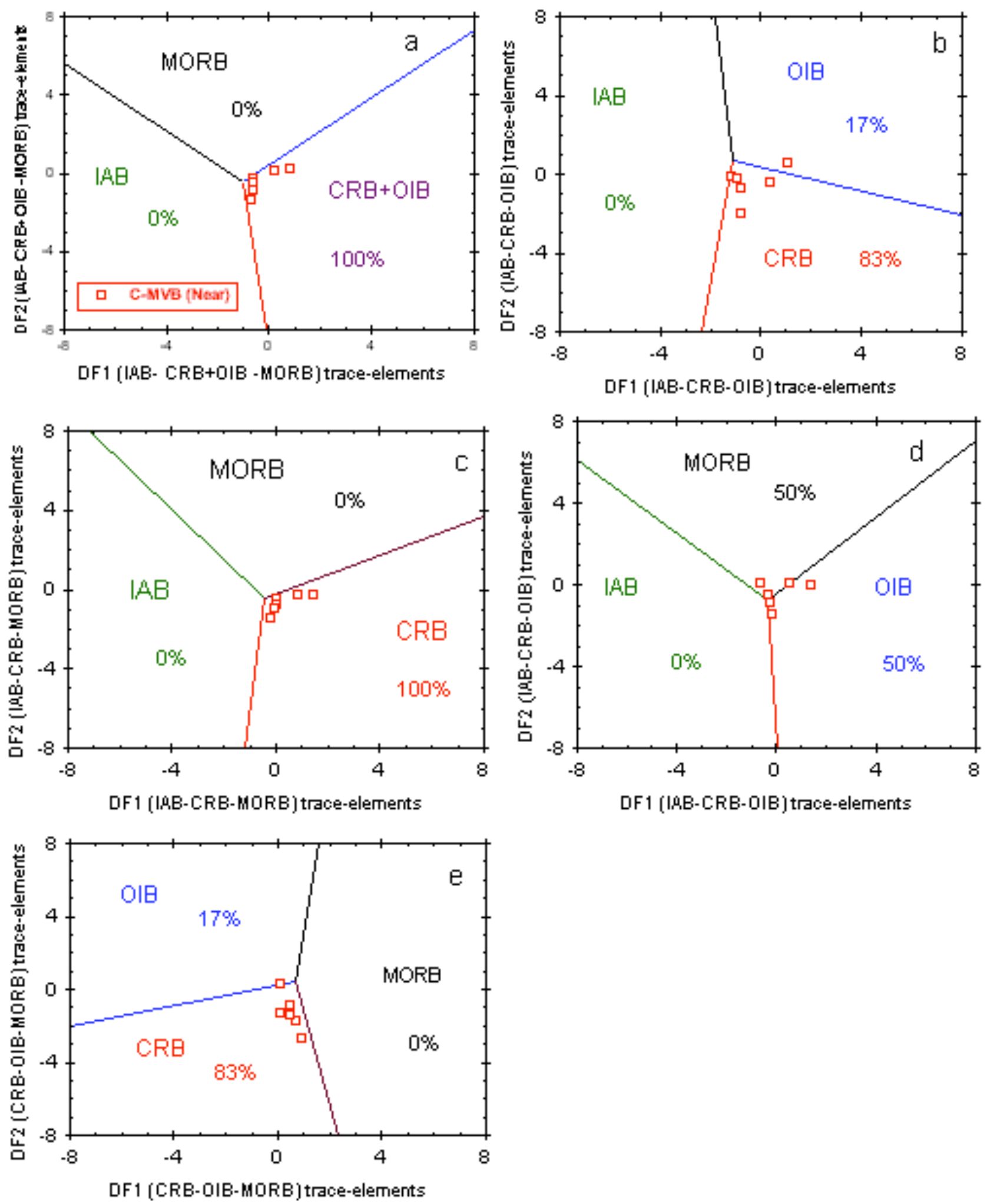

Fig. (6). All five discriminant function diagrams based on natural log-ratio transformation of trace-element ratios in basic rocks from the CMVB [128]. The percentage values given next to the tectonic setting names represent the \% success obtained for the C-MVB samples. No distinction was made between the samples from nearer to the MAT and those from farther from the trench because the total number of analyzed samples was rather small, suggesting more studies are required to increase this database. The symbols used are shown as inset in Fig. (5A). Note a $\mathrm{CRB}$ setting is clearly discernible from all diagrams in which $\mathrm{CRB}$ is present. (A) Four tectonic settings IAB-CRB+OIBMORB (Arc-Continental rift+Ocean Island-Mid-Ocean ridge). (B) Three tectonic settings IAB-CRB-OIB. (C) Three tectonic settings IABCRB-MORB. (D) Three tectonic settings IAB-OIB-MORB. (E) Three tectonic settings CRB-OIB-MORB. 
Table 1. Average Values of Chondrites, MORB, and Primitive Mantle Used for Normalization in Multi-Element Diagrams and of Bulk Silicate Earth for Slab-Sensitive and Mantle-Sensitive Parameters Used in the Present Work

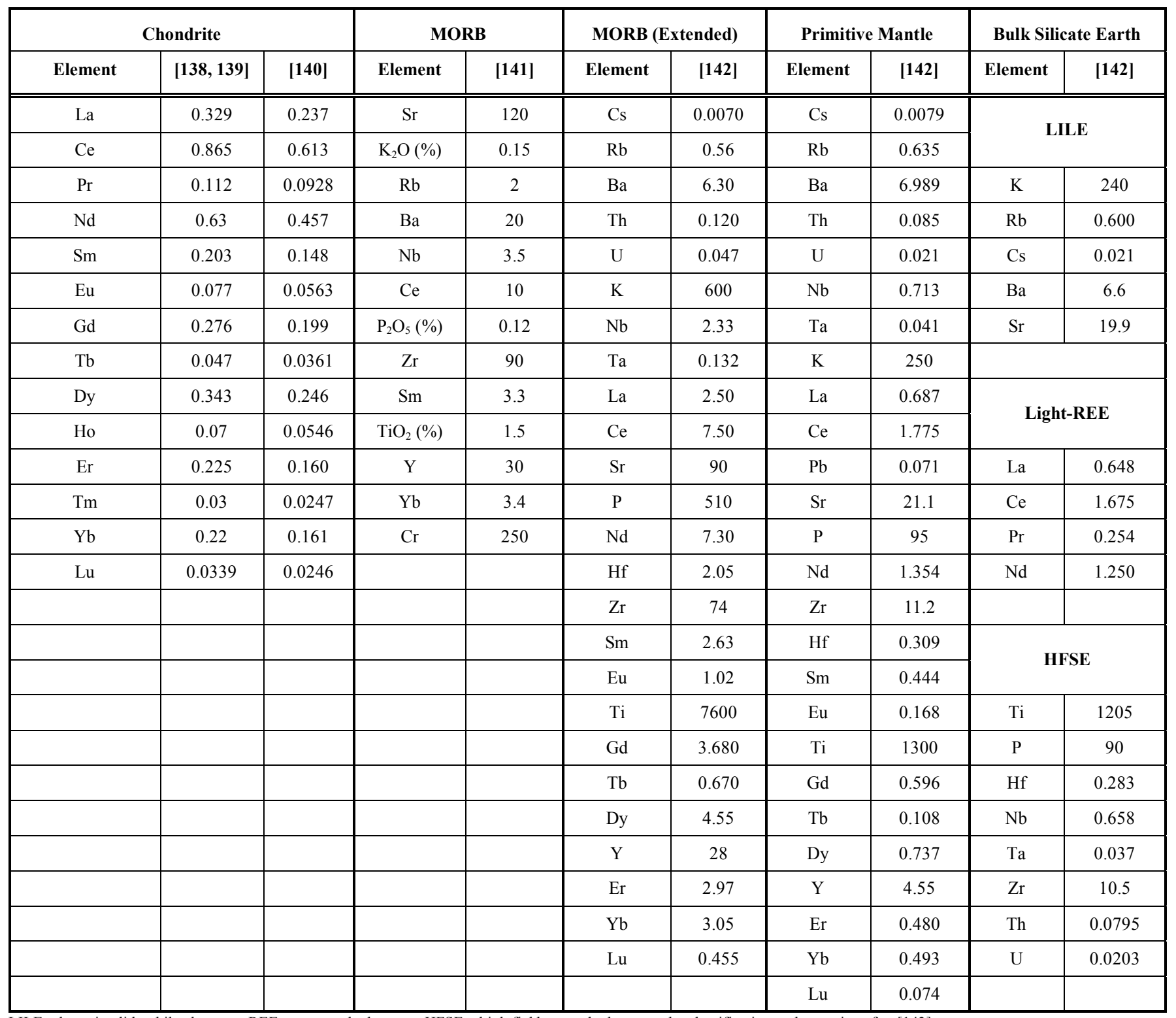

LILE - large ion lithophile elements; REE - rare-earth elements; HFSE - high field strength elements; the classification and grouping after [143].

with elements of other geochemical groups (Ba from LILE and La from REE).

I must also clarify that when for a particular sample the $\left\{\mathrm{Nb} / \mathrm{Nb}^{*}\right\}_{\mathrm{pm}}$ parameter has a small value approaching zero, one can say from the multi-element diagram that this sample shows a large negative $\mathrm{Nb}$-anomaly. On the other hand, when this parameter has a greater value, i.e., a value increasing toward 1, it means that the sample shows a small negative $\mathrm{Nb}$-anomaly. When $\left\{\mathrm{Nb} / \mathrm{Nb}^{*}\right\}_{\mathrm{pm}}$ for a given sample almost approaches 1 , it implies that this sample shows no $\mathrm{Nb}$-anomaly. Finally, when this parameter has a value $>1$, the corresponding sample shows a positive $\mathrm{Nb}$-anomaly.

The above equation (1) was used to calculate the size of the $\mathrm{Nb}$-anomaly from all compiled data. The statistics of the
$\mathrm{Nb}$-anomaly (number of samples $n$, median $\widetilde{x}$, mean $\bar{x}$, and standard deviation $S$ ) for different tectonic settings are summarized in Table 2 .

If this $\mathrm{Nb}$-anomaly parameter is calculated for all basic rock samples from a given tectonic setting, we can also estimate the $95 \%$ or $99 \%$ confidence limits of the mean using the standard deviation and Student $t$ values [144-147]. For the confidence limits to be strictly valid, the data should represent statistical samples drawn from normal populations. Therefore, appropriate measures were applied [148-155] to ascertain the validity of this assumption (see the rows marked by an asterisk in Table 2).

All island arcs and the frontal part of the two continental arcs (CAVA and Andes) show very large negative $\mathrm{Nb}$ anomalies, i.e., smaller $\mathrm{Nb}$-anomaly values (mean values of 
Table 2. Statistical Data for the Nb-Anomaly (w.r.t. Ba and La) Using Primitive Mantle Normalization, for Basic Rocks from the C-MVB (Mexico) and Their Comparison with Arcs, Rifts, Extension-Related Areas and Continental Break-Up Regions Around the World as Well as with Other Mexican Provinces (Modified After [13])

\begin{tabular}{|c|c|c|c|c|c|c|}
\hline Area & $n$ & $\tilde{\boldsymbol{x}}$ & $\bar{x}$ & $\pm s$ & $95 \% C L$ & $99 \% C L$ \\
\hline C-MVB (Mexico) farther from the trench & 15 & 0.40 & 0.48 & \pm 0.15 & $0.32-0.49$ & $0.29-0.52$ \\
\hline CAVA (front arc) & $\begin{array}{c}49 \\
* 45\end{array}$ & $\begin{array}{l}0.13 \\
0.13\end{array}$ & $\begin{array}{l}0.22 \\
0.16\end{array}$ & $\begin{array}{l} \pm 0.22 \\
\pm 0.12\end{array}$ & $\begin{array}{l}0.15-0.28 \\
0.13-0.20\end{array}$ & $\begin{array}{l}0.13-0.30 \\
0.12-0.21\end{array}$ \\
\hline CAVA (back arc) & 10 & 1.60 & 1.59 & \pm 0.29 & $1.38-1.80$ & $1.29-1.89$ \\
\hline Andes (front arc) & 245 & 0.19 & 0.21 & \pm 0.07 & $0.20-0.21$ & $0.19-0.22$ \\
\hline \multicolumn{7}{|c|}{ Island Arcs } \\
\hline Aleutian arc & $\begin{array}{c}13 \\
* 11\end{array}$ & $\begin{array}{l}0.11 \\
0.15\end{array}$ & $\begin{array}{l}0.19 \\
0.17\end{array}$ & $\begin{array}{l} \pm 0.08 \\
\pm 0.06\end{array}$ & $\begin{array}{l}0.14-0.24 \\
0.13-0.21\end{array}$ & $\begin{array}{l}0.12-0.26 \\
0.11-0.22\end{array}$ \\
\hline Burma arc & 4 & 0.09 & 0.09 & \pm 0.02 & $0.05-0.13$ & $0.02-0.16$ \\
\hline Izu-Bonin arc & $\begin{array}{l}18 \\
* 16\end{array}$ & $\begin{array}{l}0.09 \\
0.09\end{array}$ & $\begin{array}{l}0.16 \\
0.10\end{array}$ & $\begin{array}{l} \pm 0.21 \\
\pm 0.05\end{array}$ & $\begin{array}{l}0.06-0.27 \\
0.07-0.13\end{array}$ & $\begin{array}{l}0.02-0.31 \\
0.06-0.14\end{array}$ \\
\hline Japan arc & $\begin{array}{c}7 \\
* 6\end{array}$ & $\begin{array}{l}0.14 \\
0.14\end{array}$ & $\begin{array}{l}0.19 \\
0.15\end{array}$ & $\begin{array}{l} \pm 0.15 \\
\pm 0.09\end{array}$ & $\begin{array}{l}0.05-0.33 \\
0.05-0.24\end{array}$ & --- \\
\hline Luzon arc & 4 & 0.31 & 0.30 & \pm 0.10 & $0.14-0.47$ & $\sim 0.01-0.60$ \\
\hline Marianas arc & 8 & 0.07 & 0.07 & \pm 0.04 & $0.04-0.11$ & $0.02-0.12$ \\
\hline New Hebrides arc & 10 & 0.14 & 0.16 & \pm 0.04 & $0.12-0.19$ & $0.11-0.20$ \\
\hline Papua-New Guinea arc & 3 & 0.11 & 0.09 & \pm 0.02 & $0.04-0.15$ & --- \\
\hline Philippines arc & 20 & 0.22 & 0.21 & \pm 0.07 & $0.18-0.25$ & $0.17-0.26$ \\
\hline Sangihe arc & 3 & 0.16 & 0.16 & \pm 0.01 & $0.13-0.19$ & $0.09-0.23$ \\
\hline Sunda-Banda arc & 23 & 0.15 & 0.15 & \pm 0.08 & $0.11-0.18$ & $0.10-0.20$ \\
\hline Tonga-Kermadec arc & 8 & 0.14 & 0.15 & \pm 0.08 & $0.08-0.22$ & $0.05-0.26$ \\
\hline Vanuatu arc & 5 & 0.06 & 0.06 & \pm 0.02 & $0.03-0.09$ & $0.01-0.11$ \\
\hline \multicolumn{7}{|c|}{ Rifts and Extension-Related Areas: with Negative Nb-Anomaly } \\
\hline Basin and Range (BR, USA) & 34 & 0.64 & 0.69 & \pm 0.33 & $0.58-0.81$ & $0.54-0.85$ \\
\hline Colorado Plateau-Transition. BR (USA) & 39 & 0.63 & 0.63 & \pm 0.19 & $0.57-0.69$ & $0.50-0.74$ \\
\hline Rio Grande rift & 35 & 0.81 & 0.77 & \pm 0.43 & $0.62-0.91$ & $0.57-0.97$ \\
\hline \multicolumn{7}{|c|}{ Rifts and Extension-Related Areas: with Positive Nb-Anomaly } \\
\hline Central Afar (Ethiopia) & 13 & 1.16 & 1.20 & \pm 0.28 & $1.03-1.37$ & $0.96-1.43$ \\
\hline East China & 86 & 1.24 & 1.21 & \pm 0.25 & $1.15-1.26$ & $1.14-1.28$ \\
\hline Southeast China & 25 & 1.58 & 1.57 & \pm 0.30 & $1.45-1.69$ & $1.40-1.74$ \\
\hline Massif Central (France) & 21 & 1.51 & 1.52 & \pm 0.19 & $1.44-1.61$ & $1.41-1.64$ \\
\hline \multicolumn{7}{|c|}{ Continental Break-Up Regions: with Negative Nb-Anomaly } \\
\hline Columbia River & 3 & 0.37 & 0.41 & \pm 0.12 & $0.12-0.70$ & --- \\
\hline Deccan (India) & 12 & 0.59 & 0.61 & \pm 0.19 & $0.49-0.73$ & $0.44-0.78$ \\
\hline Greenland & 3 & 0.79 & 0.82 & \pm 0.09 & $0.59-1.05$ & $0.29-1.36$ \\
\hline Paraná & 1 & --- & & .49 & --- & --- \\
\hline \multicolumn{7}{|c|}{ Continental Break-Up Regions: with Positive Nb-Anomaly } \\
\hline Kwanza & 2 & --- & 1.41 & \pm 0.05 & $0.9-1.9$ & --- \\
\hline Wrangellia & 1 & --- & & .41 & --- & --- \\
\hline \multicolumn{7}{|c|}{ Other Mexican Provinces or Sub-Provinces } \\
\hline Eastern Alkaline Province & 97 & 0.76 & 0.80 & \pm 0.27 & $0.74-0.85$ & $0.72-0.86$ \\
\hline Eastern Mexican Volcanic Belt & 94 & 0.49 & 0.53 & \pm 0.22 & $0.48-0.57$ & $0.46-0.59$ \\
\hline Los Tuxtlas Volcanic Field & 22 & 0.61 & 0.62 & \pm 0.20 & $0.53-0.71$ & $0.50-0.74$ \\
\hline
\end{tabular}

$n$ - number of samples; $\tilde{x}$ - median; $\bar{x}$ - mean; $s$ - standard deviation; $95 \% C L-95 \%$ confidence limit of the mean; $99 \% C L-99 \%$ confidence limit of the mean. "--." means that the $99 \%$ confidence limits were not meaningful for these parameters; they were more dispersed due to very small number of samples and relatively large Student $t$ values [144-147]. * - When the median ( $\tilde{x})$ and mean $(\bar{x})$ values for the Nb-anomaly showed significant differences, the data were checked for outliers [148-155]; for these cases, the statistical data are also presented after outlier detection and elimination. Note that in such cases, the row marked by an * shows a better agreement between the two central tendency parameters (median and mean) than the preceding row. 
$\left\{\mathrm{Nb} / \mathrm{Nb}^{*}\right\}_{\mathrm{pm}} \sim 0.06-0.34$; for $95 \%$ and $99 \%$ confidence limits of the mean see Table 2). For comparison, the C-MVB shows much smaller negative $\mathrm{Nb}$-anomalies (mean values 0.48-0.54), with both parts (nearer to and farther from the MAT) depicting overlapping $95 \%$ and $99 \%$ confidence limits. The extent of Nb-depletion in the C-MVB is similar to continental rifts such as the Basin and Range and Colorado Plateau of USA and continental break-up regions such as the Deccan of India (see overlapping 99\% confidence limits in Table 2). The size of the Nb-anomaly for other Mexican provinces or sub-provinces (Table 2) is also similar to the $\mathrm{C}$ MVB.

For the two continental arcs, on the other hand, the frontal and back-arc parts are very different in terms of this parameter (Table 2). Whereas the frontal parts of both arcs show very similar and large negative $\mathrm{Nb}$-anomalies, the back-arc magmas from the Andes are devoid of this anomaly and those from the CAVA show a positive $\mathrm{Nb}$-anomaly. These observations are valid when $99 \%$ confidence limits are compared.

The absence of significant differences in the $\mathrm{Nb}$-anomaly parameter between the nearer and farther parts of the CMVB, the presence of significant differences between CMVB and almost all island and continental arcs, and the similarity of C-MVB with extension-related and continental break-up regions and continental rifts, clearly support a continental rift setting for the study area. The use of this quantitative parameter of $\mathrm{Nb}$-anomaly $(99 \%$ confidence limits of the mean) thus shows an advantage over the conventional way of qualitatively examining the multi-element normalized diagrams.

\section{Statistical Analysis of Nb-Anomaly}

In order to complete the quantitative approach, I applied significance tests (Fisher F, Student t and ANOVA) [144, $146,147]$ to the data summarized in Table 2. Correct application of these tests also requires that each sample be drawn from a normal population without any statistical contamination. All tests were performed at the strict $99 \%$ confidence level as practiced by our research group in other studies [63, $146,148,152-159]$. Although these tests constitute a powerful statistical technique, they are not really recommended for small-sized statistical samples such as for Luzon arc, PapuaNew Guinea, or Sangihe arc (Table 2), because for such small sizes the $t$ values become much greater and very large differences are required for them to be statistically significant $[144,146,147]$. In this context, it may be worthwhile to mention as a good application example of the Student $t$ test in geosciences that it was possible to demonstrate that seawater alteration (palagonitization) can cause a small but statistically significant decrease in ${ }^{143} \mathrm{Nd} /{ }^{144} \mathrm{Nd}$ ratio of oceanic glasses [160], the conclusion being contrary to the common belief of the geoscientific community.

No significant differences in $\mathrm{Nb}$-anomaly were observed for the C-MVB between the nearer and farther from the trench, or between these provinces (C-MVB) with any of the other Mexican provinces (Table 2). Furthermore, the CMVB showed no significant differences with most rifts and extension-related areas as well as with continental break-up regions with negative Nb-anomaly. Continental arcs of the
CAVA and Andes, on the other hand, showed significant differences between their front and back arc areas.

Note that the size of the $\mathrm{Nb}$-anomaly is said to be greater for small values of the $\left\{\mathrm{Nb} / \mathrm{Nb}^{*}\right\}_{\mathrm{pm}}$ parameter and vice versa. For both parts of the C-MVB, the size of the Nbanomaly was smaller than that for all arcs at $99 \%$ confidence level except Kamchatka arc, for which this conclusion was valid at $95 \%$ confidence level.

\section{Slab-Sensitive and Mantle-Sensitive Parameters}

The LILE K, Rb, Cs, Sr, and Ba are generally considered to be slab-sensitive because they can be easily mobilized in fluids originating from the dehydration of the subducted slab. Complications arise for the fact that these elements are also similarly enriched in the continental crust, especially the upper crust. On the other hand, the REE are less mobilized under such subduction processes and their concentrations reflect to a greater extent the composition of the mantle, although the upper continental crust might also be enriched in light-REE. Similarly, the HFSE, such as Ti, P, Nb, Zr, Hf, $\mathrm{Ta}$, are considered fluid-immobile and thus represent mantle compositions. Again, these elements are also generally depleted in the upper continental crust. For a general classification of the chemical elements into these groups see [143]. The ratios of LILE to REE, or LILE to HFSE, are thus excellent indicators of subduction signal $[5,10,13]$, or of crustal contamination. Larger values of these ratios are indicative of subduction (or crustal) contribution in the genesis of magmas whereas smaller ones reflect mantle signatures. The complication of subduction versus crust is less important in an island arc environment where the crust is likely to be oceanic, whereas it plays a significant role where continental crust is involved as is the case of the MVB. Nevertheless, these ratios should provide a good distinction between the subduction and crustal components versus the dominantly mantle sources.

The above considerations are likely valid for basic magmas or for those magmas that largely originated in the mantle or mantle wedge and were modified to a lesser extent by crustal contamination processes. However, for more differentiated intermediate and acid magmas, complications may arise from the interaction with the crust through which the less evolved magmas should pass before eruption, and the above simple picture might not be applicable. In some cases, such evolved magmas may have formed almost entirely in the crust (crustal anatexis) rather than in the mantle.

In order to evaluate the behavior of these groups of elements in basic $\left(<52 \%\left(\mathrm{SiO}_{2}\right)_{\text {adj }}\right.$; the subscript adj refers to $100 \%$ adjusted values on anhydrous basis [107]) and intermediate $\left(52 \%-57 \%\left(\mathrm{SiO}_{2}\right)_{\text {adj }}\right)$ magmas, I decided to estimate $99 \%$ confidence limits of the mean of silicate bulk earthnormalized LILE/LREE and LILE/HFSE ratios for different tectonic settings (see Table 1 for normalizing values; [142]) where LREE are the light-REE La, Ce, Pr, and Nd. The use of other sets of normalizing values for bulk silicate earth, or of any other material for normalization purposes, will only change the absolute values of these ratios, and not their trends. Therefore, the inferences drawn from this methodology will remain unchanged. 

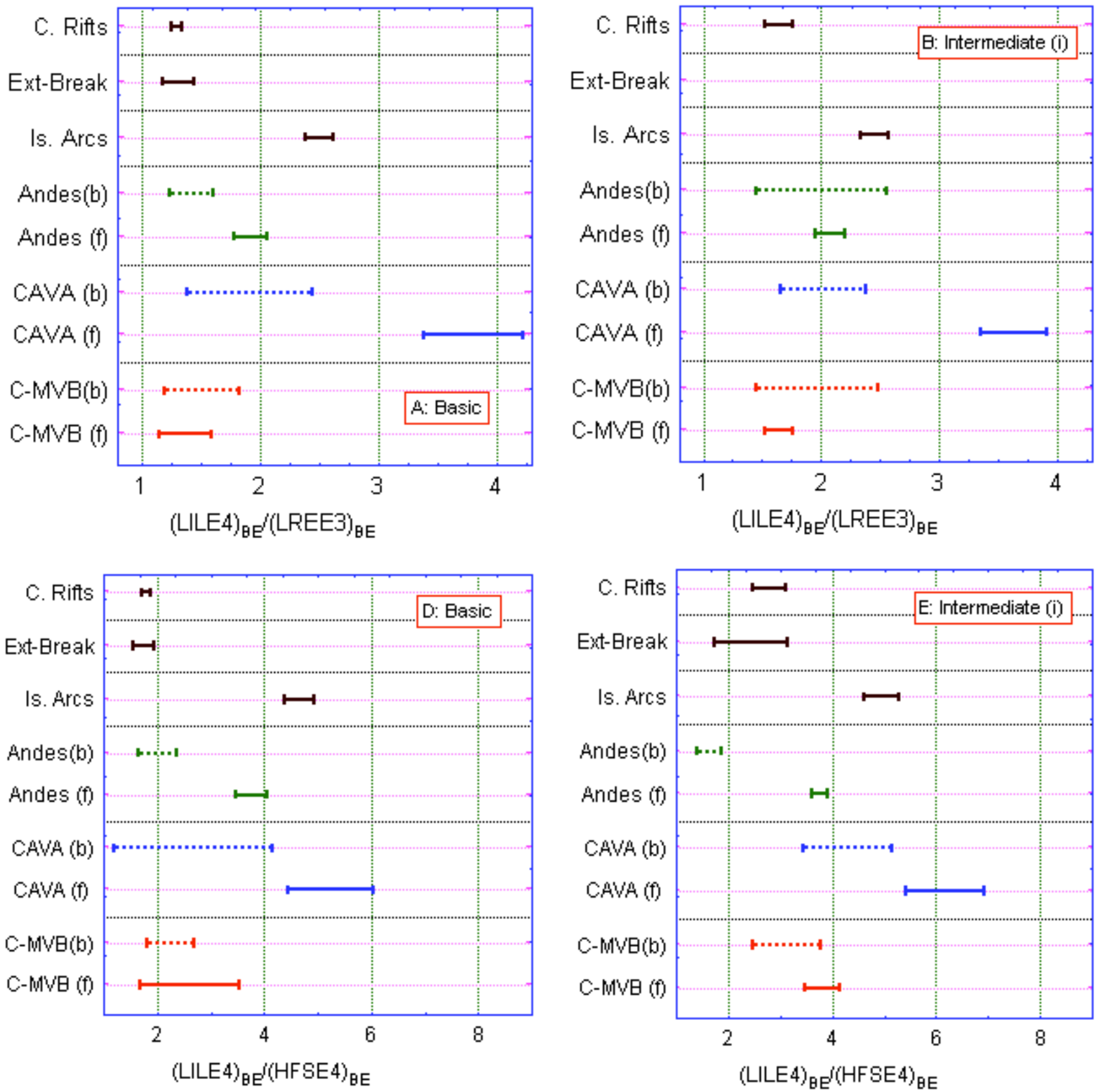

Fig. (7). Slab- (or crust-) sensitive (LILE) and mantle-sensitive (LREE and HFSE) ratio diagrams for highlighting subduction signal for basic and intermediate rocks from C-MVB (C-MVB(f) and C-MVB(b) are for samples nearer to and farther from the MAT, respectively) and comparison with two continental arcs (CAVA and Andes; the letters (f) and (b) stand for volcanic front and back-arc, respectively), all island arcs (Is. Arcs), extension-related and break-up regions (Ext-Break), and continental rifts (C. Rifts). The horizontal bars are $99 \%$ confidence limits of the mean for different tectonic settings. Note the similarity of C-MVB with extension-related and continental break-up regions as well as with continental rifts. All concentrations were normalized to silicate bulk earth values; for more details, see equations (2) and (3) in the text. The diagrams (A) and (B) are for four large ion lithophile elements (LILE4; K, Rb, Ba, and Sr) ratios to three light rare-earth elements (LREE3; La, Ce, and Nd), whereas diagrams (C) and (D) are for the same four large ion lithophile elements (LILE4; K, Rb, Ba, and $\mathrm{Sr}$ ) ratios to four high field strength elements (HFSE4; Ti, P, Nb, and $\mathrm{Zr}$ ). See text for more details.

In this study, the choice of the elements to represent a given group depended on the availability of a large number of analyses in the compiled databases. Four elements $\mathrm{K}, \mathrm{Rb}$, $\mathrm{Ba}$, and $\mathrm{Sr}$, represented the LILE group; I called them LILE4 and when normalized to bulk earth, this parameter was designated (LILE4) $)_{\mathrm{BE}}$. The LREE were three elements $\mathrm{La}, \mathrm{Ce}$ and $\mathrm{Nd}$, called (LREE3) $)_{\mathrm{BE}}$, and the HFSE were represented by four elements $\mathrm{Ti}, \mathrm{P}, \mathrm{Nb}$, and $\mathrm{Zr}$, called (HFSE4) BE $_{\mathrm{BE}}$.

The first subduction signal indicator ratio was:

$$
(\mathrm{LILE} 4)_{\mathrm{BE}} /(\mathrm{LREE} 3)_{\mathrm{BE}}=\frac{\left[(\mathrm{K})_{\mathrm{BE}}+(\mathrm{Rb})_{\mathrm{BE}}+(\mathrm{Ba})_{\mathrm{BE}}+(\mathrm{Sr})_{\mathrm{BE}}\right] / 4}{\left[(\mathrm{La})_{\mathrm{BE}}+(\mathrm{Ce})_{\mathrm{BE}}+(\mathrm{Nd})_{\mathrm{BE}}\right] / 3}
$$


Similarly, the other subduction signal indicator ratio was:

$$
(\mathrm{LILE} 4)_{\mathrm{BE}} /(\mathrm{HFSE} 4)_{\mathrm{BE}}=\frac{\left[(\mathrm{K})_{\mathrm{BE}}+(\mathrm{Rb})_{\mathrm{BE}}+(\mathrm{Ba})_{\mathrm{BE}}+(\mathrm{Sr})_{\mathrm{BE}}\right] / 4}{\left[(\mathrm{Ti})_{\mathrm{BE}}+(\mathrm{P})_{\mathrm{BE}}+(\mathrm{Nb})_{\mathrm{BE}}+(\mathrm{Zr})_{\mathrm{BE}}\right] / 4}
$$

The results of these calculations for basic and intermediate magmas are shown in Fig. (7).

This technique of combining several elements from a chemical group in the numerator and denominator of a single parameter is superior to using single element ratios, i.e., the

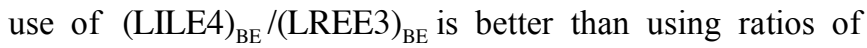
individual elements, such as $\mathrm{K} / \mathrm{La}, \mathrm{Rb} / \mathrm{Ce}, \mathrm{Ba} / \mathrm{La}$, etc. In fact, the parameters proposed as equations (2) and (3) are capable of describing the average behavior of a large number of simple element ratios, but have the advantage of not requiring the examination of a large number of combinations of two variables at a time. It should also be stressed that the actual values used for bulk earth (BE) do not really matter, because a different set of values would provide exactly the same statistical conclusions. Finally, the choice of element selection from these geochemical groups depended on the availability of a larger number of samples with complete analyses.

More differentiated intermediate and acid magmas, with $\left(\mathrm{SiO}_{2}\right)_{\text {adj }}>57 \%$, were not compared in this work because as stated above, the crustal signature might become more significant for them. The continental crust being highly heterogeneous, such effects can largely hide the mantle signature. Furthermore, because the continental crust can provide signatures similar to the subduction signal, subjective conclusions could consequently be drawn about their mantle sources.

First of all, it should be pointed out that some of the $99 \%$ confidence limits, particularly for the CMVB (b) and CAVA (b), are relatively wide. They can be probably narrowed down in future by analyzing a greater number of samples from these areas and by restricting the $\left(\mathrm{SiO}_{2}\right)_{\text {adj }}$ range for the statistical analysis.

The following observations about the $99 \%$ confidence limits of the mean of these two ratios (subduction signal) can be made (refer to Fig. 7A-D). Note that the graphical conclusions were confirmed by the Student $\mathrm{t}$ and ANOVA tests [144, 146, and 147].

i. The C-MVB samples nearer to (identified by $\mathrm{f}$ ) and farther (identified by b) from the MAT show overlapping values for these subduction signal parameters, which is not consistent with the arc-trench (MVBMAT) relationship. In theory, if the C-MVB were to result from the subduction process of the Cocos plate along the north-western part of the MAT, CMVB (f) should show significantly greater subduction signal than the CMVB (b), i.e, if the chemical composition of the C-MVB were affected by the fluids or melts of the subducted slab, it should clearly be shown in statistically significant differences of these parameters. Interestingly, this is actually the case of the two continental arcs compiled in this study (see points (ii) below), which confirms my statistics-based interpretation. ii. In both continental arcs (CAVA and Andes) the volcanic front (f) magmas show a significantly greater subduction signal than the back-arc (b) magmas. Both parameters of the $\mathrm{x}$-axis (Fig. 7A-D) show significantly greater values for the (f) than for the (b) region. This is especially notable for the CAVA and firmly establishes the arc-trench (CAVA-MAT) relationship resulting from the subduction of the same Cocos plate.

iii. The samples from both parts ( $f$ and $b$ ) of the C-MVB are generally similar to the back-arc region of the CAVA and Andes, i.e., both CMVB (f) and CMVB (b) show 99\% confidence limits of the mean that overlap with the CAVA (b) and Andes (b). On the contrary, both parts of the C-MVB show significantly different values than the frontal part of the CAVA. An exception may be the overlapping confidence limits of C-MVB with Andes(f), which is probably related to varying tectonic regime of the Andes from normal (steep) subduction to sub-horizontal type during its long ( $\sim 90 \mathrm{Ma})$ history. Therefore, the Andean samples for this comparison should have been separated according to their ages, and only those samples that corresponded to "normal" subduction should have been called Andes (f). This will be done in a future study.

iv. Nevertheless, in spite of the similarities recognized in (iii) above, the entire C-MVB cannot be interpreted as a back-arc because then an active arc must exist between this area and the MAT (Fig. 1), which is clearly not present. I stress on the word "active", because the subduction of the Cocos plate beneath the North American plate is an active, ongoing process.

v. The island arcs from around the world show strong subduction signal in terms of these two parameters, whose values are generally intermediate between the CAVA and Andes.

vi. All extension-related and continental break-up regions and continental rifts show much smaller values of these parameters than the arcs.

vii. The mean values (confidence limits) for the C-MVB magmas are similar to extension-related and continental break-up regions and continental rifts, but significantly smaller than those for the island arc magmas.

From these observations, one can clearly conclude that the C-MVB magmas represent a rift or extensional setting rather than an arc setting.

\section{OTHER GEOSCIENTIFIC CONSIDERATIONS}

In this section, I summarize other scientific arguments that provide constraints on the tectonic setting and origin of magmas in the MVB. One problem with the interpretation of geoscientific data from the MVB is that it is underlain by a heterogeneous continental crust and not an oceanic crust. It would have been easier to interpret the data if it had a thin oceanic crust because processes in the mantle would then dominate the decisions and interpretations. Therefore, the lack of consensus for the MVB may partly be due to this shallow level complexity in the genesis of magmas. 


\section{Geology and Structures}

The MAT has a unique morphology showing a break near the Mexico-Guatemala border [32, 161]. To the north of the Tehuantepec Ridge (TeR in Fig. 1), the continental shelf is narrow and the continental margin is largely a steep continental slope, whereas, south of this ridge, the continental shelf is underlain by a wide fore-arc basin presenting a classic arc-trench relationship between the CAVA and the MAT. When the distances between the MAT and the Pacific coasts of Mexico and Central America are compared (Fig. 1; see also maps of Mexico and Central America not presented here), a wider area representing a fore-arc basin is clearly visible in Central America. Thus, the geomorphology of the Pacific coast of southern Mexico lacks a fore-arc basin.

Similarly, it can be observed in Fig. (1) that the CAVA is subparallel to the MAT whereas the MVB makes an angle of about $15-20^{\circ}$ with the MAT $[162,163]$. This non-parallelism has given rise to several hypotheses to explain the origin of the MVB [5, 25, 27, 36, 163-165].

The MVB is characterized by extensive fracture and fault systems. In fact, in the western MVB a well-defined triple junction with three rifts has been proposed [166-169]. In west-central to eastern MVB also numerous studies have documented such extensional features [25, 72, 170-178]. Some authors [179] have even called them as intra-arc extension, assuming that the MVB is an arc.

Dominantly east-west extension in the C-MVB has also been inferred from the orientation and distribution of more than 200 monogenetic volcanoes in the Sierra de Chichinautzin area [24]. In the C-MVB, in fact, seven different graben systems (Ajacuba, Pachuca, Zempoala, TlalliSanta Catarina, Chichinautzin-Izta-Malinche, Ciudad de México, and Acambay) have actually been mapped and documented [29, 178]; most of these graben systems run approximately east-west, being sub-parallel to the MVB and are consistent with dominantly north-south extension. Extensional features and fault structures are not limited to the MVB, but they have been mapped throughout from the CMVB to the Pacific coast $[180,181]$. These observations are important against the arc-trench relationships for the MVBMAT because the subduction process is likely to cause compressional features between the trench and the volcanic front.

\section{Geochemical Constraints}

The failure of generalized arc-models for the MVB has been long recognized [182]. Besides, the extensional tectonics in the western part of the MVB has played a significant role in the eruption of primitive magmas [35]. I, either alone $[5,22,26,28,30,32,55,69-71]$ or with colleagues $[24,27$, $29,31,64,66,182-186]$ published a series of papers on the MVB, involving major- and trace-elements and radiogenic isotopes. Some of them included petrogenetic modeling. These studies showed as far back as in 1983 [22] for Los Humeros caldera, or in 1988 [182] for the MVB and in 1999 $[24,26]$ for the Sierra de Chichinautzin in the C-MVB(f) that this volcanic province (MVB) is atypical and its origin can be best explained from the ongoing rifting or extensional processes rather than ongoing subduction. In fact, in one of my earlier papers [5] I summarized the geoscientific information for the entire southern Mexico and Central America from Guatemala to northwestern Costa Rica and affirmed the Mexican case as unique on the Earth on the basis of quantitative arguments from seismology (depth to Wadati-Benioff zone), trace element geochemistry $(\mathrm{Ba} / \mathrm{La}, \mathrm{La} / \mathrm{Yb}, \mathrm{Ba} / \mathrm{Zr}$, and $\mathrm{Be} / \mathrm{Ce}$ ratios), and radiogenic isotopes $\left({ }^{87} \mathrm{Sr} /{ }^{86} \mathrm{Sr}\right.$, ${ }^{143} \mathrm{Nd} /{ }^{144} \mathrm{Nd},{ }^{207} \mathrm{~Pb} /{ }^{204} \mathrm{~Pb}$, and ${ }^{207} \mathrm{~Pb} /{ }^{204} \mathrm{~Pb}$ ratios, and above all, a new ratio parameter $\varepsilon_{\mathrm{Nd}} / \varepsilon_{\mathrm{Sr}}$ ).

The presence of disequilibrium phenocryst assemblages is a common characteristics in several volcanoes of the CMVB, which has been interpreted as mixing of magmas in crustal reservoirs [49, 187-191] and makes indispensable to take into account shallow-level processes before inferring about the deeper mantle and subduction processes. In fact, through the study of differentiated volcanic products of stratovolcanoes such as Iztaccíhuatl [49, 187], Popocatépetl [5961], or Nevado de Toluca [43], it would be almost impossible to unequivocally infer the deeper mantle processes, because the (continental) crustal processes can generally account for all observations, and there will be no objective way to separate the effects of processes taking place at shallower crustal depths from the deeper mantle. Similar problem may reside with the interpretation of deeper processes from the study of melt inclusions in minerals that have been reequilibrated at shallow, crustal depths [192]; in such cases the inference being made might refer to shallow processes and not deep-seated mantle sources. Therefore, inferences about the deeper processes, such as the involvement of subduction fluids or melts, cannot be easily and unequivocally made from such studies. Study of primitive magmas is therefore a fundamental requirement if one wishes to conclude about the deeper mantle sources and processes [13].

The distribution of magma types, both in space and time, is not consistent with generalized arc-models $[33,34,163$, 182; see also Fig. (3)]. Some authors [53] have used a simplistic and erroneous approach, already criticized by [185], whereby the mere presence of calc-alkaline (should be better called sub-alkaline according to the TAS diagram; [107]) magmas have been interpreted to prove their subduction relationship.

On the other hand, the apparently systematic variations of geochemical parameters with distance from the trench documented by [18] are illusive because they can well be explained by the systematically more differentiated rocktypes being sampled in their database as the MVB-MAT distance increases. These authors [18] should have examined the variations of element concentrations, or more appropriately their ratios with the distance from the trench at a given $\mathrm{SiO}_{2}$ level. Their interpretation has been recently criticized by [63].

Finally, for the unusual basic magmas from the MVB the nomenclature of ocean island basalt used by some authors [OIB, e.g., 20, 36] seems to be incorrect and should be abandoned, because the new discriminant function based discrimination diagrams [125-128] can actually distinguish between ocean island and continental rift settings and such magmas from the MVB are shown to belong to the continental rift setting, not the OIB setting. 


\section{Inverse Modeling of Geochemical Data of Primitive Magmas from Southern Mexico}

Inverse modeling of geochemical data is a powerful quantitative technique [193-199]. Basic magmas with characteristics of primitive, little-differentiated magmas are present throughout the MVB $[5,32,33,35,54,55]$ as well as in the LTVF [13, 200, 201]. The geochemical data for some of them have been subjected to inverse modeling using the procedures proposed earlier [193-199]. Specifically, data from the Sierra de Chichinautzin in the C-MVB were modeled by [29]; these authors concluded that the primitive magmas represented partial melts from the underlying mantle without the involvement of the subducted slab. Later, I extended this work to the west-central to eastern MVB [32] and to the LTVF [13], ascertaining for these regions the same conclusion as that reached by us [29] for the Sierra de Chichinautzin. Thus, quantitative interpretation of the chemistry of primitive magmas from these areas in terms of inverse modeling also confirms the inferences from other statistical arguments outlined in this paper.

\section{$\mathrm{Sr}, \mathrm{Nd}, \mathrm{Pb}, \mathrm{Os}$, and Be Isotopes}

Isotopic compositions have proved to be extremely useful in petrogenetic studies of volcanic provinces [202-204], and the MVB has been no exception. Numerous studies have been published on $\mathrm{Sr}, \mathrm{Nd}$, and $\mathrm{Pb}$ isotopes $[5,22,26,28,30$, $34,63,64,69,70,188,205-207]$. The shift to the right of the mantle array [13], towards the composition of subducted slab $[5,55]$, commonly observed in all arcs around the world, has not been yet noticed in the MVB, which once again makes this volcanic province atypical. An important point to mention here is that the $\mathrm{Sr}$ and $\mathrm{Nd}$ isotope data should be adjusted to given reference values of the standards used for estimating mass spectrometric bias, as has been done in all studies on the MVB published by our group [5, 26, 28, 30, $34,44,63,64,69,70,205,206]$. Other scholars studying the MVB have unfortunately not followed this convention [18, 43,57 , and 207].

Studies [43] reporting isotopic compositions of the socalled adakitic rocks from the MVB have not confirmed the true adakitic nature of the studied rocks because their isotopic compositions are totally different from those for the subducting Cocos plate [55]. Other geochemical characteristics of these "adakites" also cannot be obtained from the partial melting of subducting Cocos plate, being a requisite to call them as adakites. Similarly, models involving slab melts for the genesis of some MVB magmas [40, 207] are not consistent with the composition of the subducting slab $[5,55]$. Finally, osmium [208, 209] and beryllium [210] isotopic compositions of the MVB magmas have not provided any convincing results in favor of the subductionrelated origin, although these authors have tried to explain their results in terms of such arc-trench models.

\section{Geophysical Constraints}

\section{Seismology}

From earthquake data the reconstruction of the trace of the subducted slab in Central America has been a typical textbook type example for the subduction tectonics. The slab can be traced to more than $200 \mathrm{~km}$ depth, and the depth contours are subparallel to the trench as is the case of the main arc (CAVA). The CAVA lies above the slab at about 100 to $200 \mathrm{~km}$ depth (Fig. 1). The southern Mexico situation is totally anomalous because only the shallow part of the subducted slab up to about $60 \mathrm{~km}$ deep can be interpreted in front of the MVB; these contours lie far away from the volcanic front of the MVB toward the trench. Surprisingly, the deeper contours of 80 to $100 \mathrm{~km}$ suddenly terminate between the volcanic front of the eastern part of the MVB and the LTVF. Even this interpretation of seismic data corresponding to the LTVF has already been criticized [13]. No deep earthquakes are ever recorded beneath the MVB.

Interestingly, note that although the horizontal distance of the study area of the C-MVB (Fig. 2) is between about 250 and $500 \mathrm{~km}$, the subducted slab can only be traced to about $60 \mathrm{~km}$ depth (or even less) at about $230 \mathrm{~km}$ horizontal distance from the MAT and no deeper. Even the most recent seismic study [211] does not show any conclusive evidence concerning the location of the subducted slab beneath the CMVB, although these authors speculated the slab to become "horizontal", "attached" to the lower part of the continental crust and then suddenly "steeply dip" into the mantle without any seismic signal, well before reaching the volcanic front of the C-MVB. Because it would be impossible to generate magmas from the interaction of such a shallow slab (about $40 \mathrm{~km}$ depth), the authors speculated the steep turn in slab geometry. Their low-velocity zone supposed to prove the presence of subduction fluids [211] beneath the C-MVB can be readily and more appropriately explained in the rifting scenario. In fact, the continental rift setting of the C-MVB would be consistent with all the seismic evidence presented by these authors [211] and with the statistical interpretation of the geochemical data documented in the present paper.

No deep earthquakes have been observed beneath the entire study area; instead, very shallow earthquakes are commonly observed, e.g., the 1995 earthquake of Milpa Alta at only about $12 \mathrm{~km}$ depth [212]. These shallow earthquakes in fact constitute good evidence in favor of the ongoing extensional or rifting processes within the MVB. Almost all earthquakes deeper than about $40 \mathrm{~km}$ related to the Mexican subduction zone are of extensional type rather than of compression, and the subduction is subhorizontal with an angle of only about $15^{\circ}$ [212-214], or even lesser dip according to the most recent study [211]. Transtensive deformation in the C-MVB has been attributed to the oblique convergence and slip partitioning at the MAT [215].

To reconcile this anomalous situation and to continue to conform to the conventional subduction-related models, the authors of [216] used the deep earthquakes probably corresponding to the Rivera plate in the Jalisco State of the western part of the MVB [217, 218], and imagined the existence of the Cocos subducted slab somewhat deeper beneath the central and eastern parts of the MVB. It is not clear why in this seismic study [216] the two plates (Rivera and Cocos) were considered as though they were a single plate. After all, the existence of the small Rivera plate has been established as independent of the Cocos plate $[219,220]$. The experimental uncertainties inevitably present in the earthquake depth locations are never taken into account in any seismic study; after all, these are experimentally determined parameters and are not absolute locations within the Earth. 
This rather subjective interpretation [216] was already criticized [30], but the scientific community has paid little attention to this controversial interpretation of earthquakes to infer the position of the subducted Cocos plate beneath southern Mexico. Instead, numerous researchers [18, 39, 40, and 57] have taken it for granted that these hypothetical contours actually exist and made them a fact by simply repeating them in their papers. In the recent work related to Rivera plate seismicity [221], the authors have, however, interpreted that the subducted Rivera plate lies well away from the volcanic front towards the trench in the western MVB, which is again an unusual conclusion if the volcanism in the western MVB were to be related to the subduction of this plate beneath Mexico.

\section{Magnetotelllurics}

Magnetotelluric data acquired along a transect from the Pacific coast thorough the C-MVB and to the north [222] showed a low-resistivity zone beneath the C-MVB, which may well be consistent with the continental rift setting proposed in the present work.

\section{Gravity}

Gravimetric studies [223, 224] have shown that partial melts exist in the lower crust beneath the MVB, making the lower crustal involvement in the genesis of magmas a feasible process $[5,26,225]$. Crustal contamination has been invoked in several studies of evolved magmas from the MVB [28, 30, 31, 64, 66, 69-71, 226, 227].

This alternative lower crustal reservoir is likely to impart similar signatures as those from the subducted slab to intermediate and acid magmas in the MVB, and therefore the controversy concerning the origin of this province cannot be resolved from the study of such evolved magmas. These dual possibilities - subducted slab versus lower crust - will have to be taken into account, and the origin of basic, primitive magmas will have to play a central role in such decisions. Under these constraints, the origin of the MVB will necessarily have to be related to a continental rift setting as shown in the present work.

\section{Thermal Modeling}

Thermal modeling of the combined Cocos and North American plates has been carried out [17] and used by other researchers as a valid argument in favor of the subductionrelated origin of the MVB. Although, in this modeling work, there might be several objections and probable misinterpretations of the tectonics of this complex area, the main objection lies in the starting conceptual tectonic model that these authors [17] have used, viz., the subducted plate or slab is supposed to exist not only beneath the MVB but also far beyond through NW Mexico up to the State of Luisiana or Texas in the U.S.A. - an absurd scenario indeed! More recently, in a combined seismic and thermal modeling study of the C-MVB [211] these authors showed a low velocity shallow zone interpreting it as a result of subduction fluids. I would better interpret this zone as a result of rift-related partial melting upwelling zone, which is also consistent with the interpretation of the gravity data [223] and shallow level seismicity recorded beneath the C-MVB [212] as well as with the quantitative statistical interpretation of the geochemical data documented in the present paper.

Thus, a more realistic starting model has to be used to correctly carry out this kind of thermal modeling, and a 3-D model would be more appropriate such as that recently practiced by us [228] for the Los Humeros caldera located in the eastern part of the MVB. Furthermore, a more complete thermal model should take into account the subduction of the entire Cocos plate, both beneath the Caribbean and North American plates.

\section{FINAL REMARKS}

It may be worthwhile to stress the great complexity of the C-MVB in particular and the MVB in general, as has been correctly pointed out recently by [229], but there is no justification to call this volcanic province a volcanic arc [209, 229]. It should better be called a continental rift. In other words, the Mexican Volcanic Rift might be a better nomenclature to the MVB if one is not satisfied by its present name - the Mexican Volcanic Belt. The complexity of the MVB might be similar to (or even greater than) that of the southern Central America from central Costa Rica to Panama, where unlike Guatemala to northwestern Costa Rica, the geochemistry is not arc-like, and a plethora of different models have been put forth [230-237]. I suggest that the scholars studying the MVB become more objective in their approach, take into account all available scientific arguments to reach unbiased inferences, clearly distinguish facts from fiction, or evidence from imagination, and practice a quantitative rather than a qualitative methodology. We might thus eventually reach a consensus in our thinking about the Mexican Volcanic Belt.

\section{CONCLUSION}

In summary, from the geological, geochemical and geophysical evidence summarized in this paper and the new, quantitative, robust, objective statistical approach practiced here, one can safely conclude that the tectonic setting of the C-MVB is dominantly related to the ongoing extension. More geochemical data are needed from this area to better constrain the confidence limits of the mean presented in this paper and draw conclusions at even greater confidence level than the $99 \%$ used in the present work. Finally, it appears that the subduction setting for the MVB advocated by numerous workers probably has resulted from subjective, qualitative arguments, which have been shown to fail when the same information compiled in this paper was examined by the quantitative statistics-based methodology.

\section{ACKNOWLEDGEMENTS}

I am grateful to the staff of the Open Geology Journal for having extended the invitation to contribute as a member of the Editorial Advisory Board of this journal. Having written a single-author book on statistics and having guided a bachelor-level thesis of F. Hernández-Coronado motivated me to explore this new frontier in the study of the Mexican Volcanic Belt. I am also much grateful to three anonymous reviewers, all of whom although greatly appreciating this work, offered numerous suggestions to help improve my presentation. Comments from Hetu C. Sheth who provided an unofficial review of an earlier version of this paper, were also helpful for its improvement. 


\section{REFERENCES}

[1] G. V. Burbach, C. Frohlich, W. D. Pennington, and T. Matumoto, "Seismicity and tectonics of the subducted Cocos Plate", J. Geophys. Res., vol. 89, pp. 7719-7735, 1984.

[2] A. Demant, "Características del Eje Neovolcánico Transmexicano y sus problemas de interpretación”, Rev. Inst. Geol. UNAM, vol. 2, pp. 172-187, 1978.

[3] S. Pal, M. M. Lopez, J. R. Pérez, and J. D. Terrell, "Magma characterization of the Mexican Volcanic Belt (Mexico)", Bull. Volcanol., vol. 41, pp. 379-389, 1978.

[4] M. Protti, F. Güendel, and K. McNally, "Correlation between the age of the subducting Cocos plate and the geometry of the WadatiBenioff zone under Nicaragua and Costa Rica", Geol. Soc. Am. Spec. Pap., vol. 295, pp. 309-326, 1995.

[5] S. P. Verma, "Absence of Cocos plate subduction-related basic volcanism in southern Mexico: a unique case on Earth?", Geology, vol. 30, pp. 1095-1098, 2002.

[6] H. C. Sheth, “'Large Igneous Provinces (LIPs)': definition, recommended terminology, and a hierarchical classification", Earth Sci. Rev., vol. 85, pp. 117-124, 2007.

[7] C. Robin, "Mexico", in Andesites, R. S. Thorpe, Ed., Chichester: John Wiley \& Sons, 1982, pp. 137-147.

[8] S. P. Verma, "Mexican Volcanic Belt. Part 1 (Preface)", Geofis. Int., vol. 24, pp. 7-18, 1985.

[9] S. P. Verma, "Mexican Volcanic Belt: present state of knowledge and unsolved problems", Geofis. Int., vol. 26, pp. 309-340, 1987

[10] M. J. Carr, M. D. Feigenson, and E. A. Bennett, "Incompatible element and isotopic evidence for tectonic control of source mixing and melt extraction along the Central American arc", Contrib. Mineral. Petrol., vol. 105, pp. 369-380, 1990.

[11] W. P. Leeman, M. J. Carr, and J. D. Morris, "Boron geochemistry of the Central American Volcanic Arc: Constraints on the genesis of subduction-related magmas", Geochim. Cosmochim. Acta, vol. 58, pp. 149-168, 1994.

[12] L. C. Patino, M. J. Carr, and M. D. Feigenson, "Local and regional variations in Central American arc lavas controled by variations in subducted sediment input", Contrib. Mineral. Petrol., vol. 138, pp. 265-283, 2000.

[13] S. P. Verma, "Extension related origin of magmas from a garnetbearing source in the Los Tuxtlas volcanic field, Mexico", Int. J. Earth Sci., vol. 95, pp. 871-901, 2006.

[14] F. Mooser, "Mexican Volcanic Belt: structure and tectonics", Geofis. Int., vol. 12, pp. 55-70, 1972.

[15] J. F. W. Negendank, R. Emmermann, R. Krawczyk, F. Mooser, H. Tobschall, and D. Werle, "Geological and geochemical investigations on the eastern Trans Mexican Volcanic Belt", Geofis. Int., vol. 24, pp. 477-575, 1985.

[16] S. Pal, and J. Urrutia Fucugauchi, "Paleomagnetism, geochronology and geochemistry of some igneous rocks from Mexico and their tectonic implications", In: Proc. IV International Gondwana Symposium, Calcutta, India: Hindustan Publishing Corporation, 1977, pp. 814-831.

[17] V. C. Manea, M. Manea, V. Kostoglodov, and G. Sewell, "Thermo-mechanical model of the mantle wedge in Central Mexican subduction zone and a blob tracing approach for the magma transport", Phys. Earth Planet. Inter., vol. 149, pp. 165-186, 2005.

[18] D. L. Blatter, G. L. Farmer, and I. S. E. Carmichael, "A north-south transect across the Central Mexican Volcanic Belt at $\sim 100^{\circ} \mathrm{W}$ : spatial distribution, petrological, geochemical, and isotopic characteristics of Quaternary volcanism," J. Petrol., vol. 48, pp. 901-950, 2007.

[19] L. Meriggi, J. L. Macías, S. Tommasini, L. Capra, and S. Conticelli, "Heterogeneous magmas of the Quaternary Sierra Chichinautzin volcanic field (central Mexico): the role of an amphibole-bearing mantle and magmatic evolution processes", Rev. Mex. Cienc. Geol., vol. 25, pp. 197-216, 2008.

[20] A. Márquez, R. Oyarzun, M. Doblas, and S. P. Verma, "Alkalic (ocean-island basalt type) and calc-alkalic volcanism in the Mexican Volcanic Belt: a case for plume-related magmatism and propagating rifting at an active margin?", Geology, vol. 27, pp. 51-54, 1999.

[21] A. Márquez, R. Oyarzun, M. Doblas, and S. P. Verma, "Reply (to Comment by L. Ferrari and J. Rosas Elguera on "Alkalic (ocean basalt type) and calc-alkalic volcanism in the Mexican volcanic belt: a case of plume-related magmatism and propagating rift at an active margin?" Comment and Reply", Geology, vol. 27, pp. 1055 1056, 1999.

[22] S. P. Verma, "Magma genesis and chamber processes at Los Humeros caldera, Mexico - Nd and Sr isotope data", Nature, vol 301, pp. 52-55, 1983.

[23] D. H. Shurbet, and S. E. Cebull, "Tectonic intepretation of the Trans-Mexicano Volcanic Belt”, Tectonophysics, vol. 101, pp. 159$165,1984$.

[24] A. Márquez, S. P. Verma, F. Anguita, R. Oyarzun, and J. L. Brandle, "Tectonics and volcanism of Sierra Chichinautzin: extension at the front of the Central Trans-Mexican Volcanic Belt", J. Volcanol. Geotherm. Res., vol. 93, pp. 125-150, 1999.

[25] A. Márquez, R. Oyarzun, C. de Ignacio, and M. Doblas, "Southward migration of volcanic activity in the central Mexican Volcanic Belt: asymmetric extension within a two-layer crustal stretching model", J. Volcanol. Geotherm. Res., vol. 112, pp. 175-187, 2001

[26] S. P. Verma, "Geochemistry of evolved magmas and their relationship to subduction-unrelated mafic volcanism at the volcanic front of the central Mexican Volcanic Belt", J. Volcanol. Geotherm. Res., vol. 93, pp. 151-171, 1999.

[27] H. C. Sheth, I. S. Torres-Alvarado, and S. P. Verma, "Beyond subduction and plumes: a unified tectonic-petrogenetic model for the Mexican Volcanic Belt", Int. Geol. Rev., vol. 42, pp. 1116$1132,2000$.

[28] S. P. Verma, "Geochemical evidence for a lithospheric source for magmas from Los Humeros caldera, Puebla, Mexico", Chem. Geol., vol. 164, pp. 35-60, 2000.

[29] F. Velasco-Tapia, S. P. Verma, "First partial melting inversion model for a rift-related origin of the Sierra de Chichinautzin volcanic field, central Mexican Volcanic Belt," Int. Geol. Rev., vol. 43, pp. 788-817, 2001.

[30] S. P. Verma, "Geochemical evidence for a lithospheric source for magmas from Acoculco caldera, eastern Mexican Volcanic Belt," Int. Geol. Rev., vol. 43, pp. 31-51, 2001.

[31] I. S. Torres-Alvarado, and S. P. Verma, "Discussion and reply: Neogene volcanism at the front of the central Mexican Volcanic Belt: basaltic andesites to dacites, with contemporaneous shoshonites and high-TiO 2 lava", Geol. Soc. Am. Bull., vol. 115, pp. 1020-1021, 2003.

[32] S. P. Verma, "Solely extension-related origin of the eastern to west-central Mexican Volcanic Belt (Mexico) from partial melting inversion model", Curr. Sci., vol. 86, pp. 713-719, 2004.

[33] J. F. Luhr, J. F. Allan, I. S. E. Carmichael, S. A. Nelson, T. Hasenaka, "Primitive calc-alkaline and alkaline rock types from the western Mexican Volcanic Belt", J. Geophys. Res., vol. 94, pp. 4515-4530, 1989.

[34] S. P. Verma and S. A. Nelson, "Isotopic and trace element constraints on the origin and evolution of alkaline and calc-alkaline magmas in the northwestern Mexican Volcanic Belt", J. Geophys. Res., vol. 94, pp. 4531-4544, 1989.

[35] J. F. Luhr, "Extensional tectonics and the diverse primitive volcanic rocks in the western Mexican Volcanic Belt", Can. Min., vol. 35, pp. 473-500, 1997.

[36] L. Ferrari, "Slab detachment control on mafic volcanic pulse and mantle heterogeneity in central Mexico", Geology, vol. 32, pp. 7780, 2004.

[37] L. Capra, J. L. Macías, and V. H. Garduño, "The Zitácuaro Volcanic Complex, Michoacán, Mexico: magmatic and eruptive history of a resurgent caldera", Geofis. Int., vol. 36, pp. 161-179, 1997.

[38] D. L. Blatter, I. S. E. Carmichael, A. L. Deino, and P. R. Renne, "Neogene volcanism at the front of the central Mexican volcanic belt: basaltic andesites to dacites, with contemporaneous shoshonites and high-TiO 2 lava", Geol. Soc. Am. Bull., vol. 113, pp. 1324-1342, 2001.

[39] S. B. Mukasa, D. L. Blatter, and A. V. Andronikov, "Mantle peridotite xenoliths in andesite lava at El Peñon, central Mexican Volcanic Belt: isotopic and trace element evidene for melting and metasomatism in the mantle wedge beneath an active arc", Earth Planet. Sci. Lett., vol. 260, pp. 37-55, 2007.

[40] A. Gómez-Tuena, C. H. Langmuir, S. L. Goldstein, S. M. Straub, and F. Ortega-Gutiérrez, "Geochemical evidence for slab melting in the Trans-Mexican Volcanic Belt", J. Petrol., vol. 48, pp. 537562, 2007. 
[41] A. García-Palomo, J. L. Macías, J. L. Arce, L. Capra, V. H. Garduño, and J. M. Espíndola, "Geology of Nevado de Toluca volcano and surrounding areas, Central Mexico", Geol. Soc. Am. Map Chart Ser., vol. MCH089, p. 26, 2002.

[42] J. L. Arce, J. L. Macías, and L. Vázquez-Selem, "The 10.5 ka Plinian eruption of Nevado de Toluca volcano, Mexico: stratigraphy and hazard implications", Geol. Soc. Am. Bull., vol. 115, pp. 230-248, 2003.

[43] R. G. Martínez-Serrano, P. Schaaf, G. Solís-Pichardo, M. S. Hernández-Bernal, T. Hernández-Treviño, J. J. Morales-Contreras, and J. L. Macías, "Sr, $\mathrm{Nd}$ and $\mathrm{Pb}$ isotope and geochemical data from the Quaternary Nevado de Toluca volcano, a source of recent adakitic magmatism, and the Tenango volcanic field, Mexico", $J$. Volcanol. Geotherm. Res., vol. 138, pp. 77-110, 2004.

[44] K. Bloomfield, "The age and significance of Tenango basalt, central Mexico", Bull. Volcanol., vol. 37, pp. 586-595, 1973.

[45] B. M. Gunn, F. Mooser, "Geochemistry of the volcanics of central Mexico", Bull. Volcanol., vol. 34, pp. 577-613, 1971.

[46] J. F. W. Negendank, "Volcanics of the Valley of Mexico. Description of some Mexican volcanic rocks with special consideration of the opaques. Part I: petrography of the volcanics", Neues Jb. Miner. Abh., vol. 116, pp. 308-320, 1972.

[47] K. Bloomfield, "A late-Quaternary monogenetic volcano field in central Mexico", Geol. Rundsch., vol. 64, pp. 476-497, 1975.

[48] J. R. Pérez, S. Pal, D. J. Terrell, J. Urrutia F, and M. M. López, "Preliminary report on the analysis of some "in-house" geochemical reference samples from Mexico", Geofis. Int., vol. 18, pp. 197209, 1979

[49] T. G. Nixon, "Petrology of the Younger Andesites and Dacites of Iztaccíhuatl volcano, Mexico: II. Chemical stratigraphy, magma mixing, and the composition of basaltic magma influx", J. Petrol., vol. 29 , pp. 265-303, 1988.

[50] A. L. Martin del Pozzo, "Geoquímica y paleomagnetismo de la Sierra Chichinautzin", Ph.D. Thesis, Universidad Nacional Autónoma de México, Mexico, D.F., 1989.

[51] R. T. Swinamer, "The geomorphology, petrography, geochemistry and petrogenesis of the volcanic rocks in the Sierra del Chichinautzin”, Mexico. M. Sc. Thesis, Queen's University, Kingston, 1989.

[52] G. T. Nixon, "The geology of Iztaccíhualtl volcano and adjacent areas of the Sierra Nevada and Valley of Mexico", Geol. Soc. Am. Special Paper, no. 219, pp. 1-58, 1993.

[53] H. Delgado, R. Molinero, P. Cervantes, J. Nieto-Obregón, R. Lozano-Santa Cruz, H. L. Macías-González, C. Mendoza-Rosales, and G. Silva-Romo, "Geology of Xitle volcano in southern Mexico City - a 2000-year-old monogenetic volcano in an urban area", Rev. Mex. Cienc. Geol., vol. 15, pp. 115-131, 1998.

[54] P. J. Wallace, and I. S. E. Carmichael, "Quaternary volcanism near the Valley of Mexico: implications for subduction zone magmatism and the effects of crustal thickness variations on primitive magma compositions", Contrib. Mineral. Petrol., vol. 135, pp. 291-314, 1999.

[55] S. P. Verma, "Geochemistry of the subducting Cocos plate and the origin of subduction-unrelated mafic volcanism at the volcanic front of the central Mexican Volcanic Belt", in Cenozoic tectonics and volcanism of Mexico, H. Delgado-Granados, G. Aguirre-Díaz and J. M. Stock, Eds., Boulder, Colorado, USA: Geol. Soc. Am., 2000, pp. 195-222.

[56] C. Siebe, V. Rodríguez-Lara, P. Schaaf, and M. Abrams, "Geochemistry, Sr-Nd isotope composition, and tectonic setting of Holocene Pelado, Guespalapa and Chichinautzin scoria cones, south of Mexico City", J. Volcanol. Geotherm. Res., vol. 130, pp. 197-226, 2004.

[57] P. Schaaf, J. Stimac, C. Siebe, and J. L. Macías, "Geochemical evidence for mantle origin and crustal processes in volcanic rocks from Popocatépetl and surrounding monogenetic volcanoes, central Mexico", J. Petrol., vol. 46, pp. 1243-1282, 2005.

[58] A. C. L. Larocque, J. A. Stimac, and C. Siebe, "Metal-residence sites in lavas and tuffs from Volcán Popocatépetl, Mexico: implications for metal mobility in the environment," Environ. Geol., vol. 33, pp. 197-208, 1998.

[59] C. Robin, "Le Volcan Popocatepetl (Mexique): structure, evolution pétrologique et risques", Bull. Volcanol., vol. 47, pp. 1-23, 1984.

[60] C. Boudal, "Pétrologie d'un grand volcan andesitique mexicain: le Popocatépetl, le rộle de mélanges de magma dans les dynamisms de l'activité recente", Ph.D. thesis, Clermont-Ferrand, 1985.
[61] C. Siebe, P. Schaaf, and J. Urrutia-Fucugauchi, "Mammoth bones embedded in a late Pleistocene lahar from Popocatépetl volcano, near Tocuila, central México", Geol. Soc. Am. Bull., vol. 111, pp. 1550-1562, 1999.

[62] S. M. Straub, and A. L. Martin-Del Pozzo, "The significance of phenocryst diversity in tephra from recent eruptions at Popocatepetl volcano (central Mexico)", Contrib. Mineral. Petrol., vol. 140, pp. 487-510, 2001

[63] I. S. Torres-Alvarado, A. D. Smith, and J. Castillo-Román, "Sr, Nd, and $\mathrm{Pb}$ isotopic and geochemical constraints for the origin of magmas in Popocatépetl volcano (Central Mexico) and their relationship with adjacent volcanic fields", Int. Geol. Rev., Vol. 51, 2009, in press.

[64] S. P. Verma, G. Carrasco-Núñez, and M. Milán, "Geology and geochemistry of Amealco caldera, Qro., Mexico", J. Volcanol. Geotherm. Res., vol. 47, pp. 105-127, 1991.

[65] G. J. Aguirre-Díaz, and F. W. McDowell,"Volcanic evolution of the Amealco caldera, Central Mexico", in Cenozoic tectonics and volcanism of Mexico, H. Delgado-Granados, G. Aguirre-Díaz and J. M. Stock, Eds., Boulder, Colorado, USA: Geol. Soc. Am., 2000, pp. 179-193.

[66] S. P. Verma, and G. Carrasco-Núñez, "Reappraisal of the geology and geochemistry of Volcán Zamorano, central Mexico: implications for discriminating the Sierra Madre Occidental and Mexican Volcanic Belt provinces", Int. Geol. Rev., vol. 45, pp. 724-752, 2003.

[67] L. Ferrari, V. H. Garduño, F. Innocenti, P. Maneti, G. Pasquare, and G. Vaggelli, "A widespread mafic volcanic unit at the base of the Mexican Volcanic Belt between Guadalajara and Querétaro", Geofis. Int., vol. 33, pp. 107-123, 1994.

[68] L. Ferrari, S. Conticelli, G. Vaggelli, C. M. Petrone, and P. Manetti, "Late Miocene volcanism and intra-arc-tectonics during the early development of the Trans-Mexican Volcanic Belt", Tectonophysics, vol. 318, pp. 161-185, 2000.

[69] S. P. Verma, "Geochemical and Sr-Nd-Pb isotopic evidence for a combined assimilation and fractional crystallisation process for volcanic rocks from the Huichapan caldera, Hidalgo, Mexico", Lithos, vol. 56, pp. 141-164, 2001.

[70] S. P. Verma, "Geochemical and Sr-Nd isotopic evidence for a riftrelated origin of magmas in Tizayuca volcanic field, Central Mexican Volcanic Belt”, J. Geol. Soc. India, vol. 61, pp. 257-276, 2003.

[71] S. P. Verma, "Geochemical evidence for a rift-related origin of bimodal volcanism at Meseta Río San Juan, North-Central Mexican volcanic belt", Int. Geol. Rev., vol. 43, pp. 475-493, 2001.

[72] A. García-Palomo, J. L. Macías, G. Tolson, G. Valdez, and J. C. Mora, "Volcanic stratigraphy and geological evolution of the Apan region, east-central sector of the Trans-Mexican volcanic belt", Geofis. Int., vol. 41, pp. 133-150, 2002.

[73] C. H. Ryder, J. B. Gill, F. Tepley III, F. Ramos, M. Reagan, "Closed- to open-system differentiation at Arenal volcano (19682003)", J. Volcanol. Geotherm. Res., vol. 157, pp. 75-93, 2006.

[74] G. E. Alvarado, G. J. Soto, H.-U. Schmincke, L. L. Bolge, and M. Sumita, "The 1968 andesitic lateral blast eruption at Arenal volcano, Costa Rica", J. Volcanol. Geotherm. Res., vol. 157, pp. 9-33, 2006.

[75] L. L. Bolge, M. J. Carr, M. D. Feigenson, and G. E. Alvarado, "Geochemical stratigraphy and magmatic evolution at Arenal volcano, Costa Rica", J. Volcanol. Geotherm. Res., vol. 157, pp. 3448, 2006.

[76] S. Agostini, G. Corti, C. Doglioni, E. Carminati, F. Innocenti, S. Tonarini, P. Manetti, G. Di Vincenzo, and D. Montanari, "Tectonic and magmatic evolution of the active volcanic front in El Salvador: insight into the Berlín and Ahuachapán geothermal areas", Geothermics, vol. 35, pp. 368-408, 2006.

[77] L. Lopez-Escobar, M. Vergara, and F. A. Frey, "Petrology and geochemistry of lavas from Antuco volcano, a basaltic volcano of the southern Andes $\left(37^{\circ} 25^{\prime}\right)$ ', J. Volcanol. Geotherm. Res., vol. 11, pp. 329-352, 1981.

[78] V. A. Ramos, and S. M. Kay, "Triassic rifting and associated basalts in the Cuyo basin, central Argentina", Geol. Soc. Am., vol. Special Paper 265, pp. 79-92, 1991.

[79] P. P. Lebti, J-C. Thouret, G. Wörner, and M. Fornari, "Neogene and Quaternary ignimbrites in the area of Arequipa, southern Peru: stratigraphical and petrological correlations", J. Volcanol. Geotherm. Res., vol. 154, pp. 251-275, 2006. 
[80] B. Déruelle, "Petrology of Quaternary shoshonitic lavas of northwestern Argentina", Geol. Soc. Am, vol. Special Paper 265, pp. 201-216, 1991.

[81] S. M. Kay, and C. E. Gordillo, "Pocho volcanic rocks and the melting of depleted continental lithosphere above a shallowly dipping subduction zone in the central Andes", Contrib. Mineral. Petrol., vol. 117, pp. 25-44, 1994.

[82] C. R. Stern, F. A. Frey, K. Futa, R. E. Zartman, Z. Peng, and T. K. Kyser, "Trace-element and $\mathrm{Sr}, \mathrm{Nd}, \mathrm{Pb}$, and $\mathrm{O}$ isotopic composition of Pliocene and Quaternary alkali basalts of the Patagonian Plateau lavas of southernmost South America", Contrib. Mineral. Petrol., vol. 104, pp. 294-308, 1990 .

[83] W. Hildreth, and S. Moorbath, "Crustal contributions to arc magmatism in the Andes of central Chile", Contrib. Mineral. Petrol., vol. 98, pp. 455-489, 1988.

[84] S. M. Kay, V. Maksaev, R. Moscoso, C. Mpodozis, and C. Nasi, "Probing the evolving Andean lithosphere: mid-late Tertiary magmatism in Chile $\left(29^{\circ}-30^{\circ} 30^{\prime} \mathrm{S}\right)$ over the modern zone of subhorizontal subduction", J. Geophys. Res., vol. 92, pp. 6173-6189, 1987.

[85] J. P. Davidson, K. M. Ferguson, M. T. Colucci, and M. A. Dungan, "The origin and evolution of magmas from the San Pedro-Pellado volcanic complex, S. Chile: multicomponent sources and open system evolution", Contrib. Mineral. Petrol., vol. 100, pp. 429-445, 1988.

[86] F. A. Frey, D. C. Gerlach, R. L. Hickey, L. Lopez-Escobar, and F. Munizaga-Villavicencio, "Petrogenesis of the Laguna del Maule volcanic complex, Chile ( $\left.36^{\circ} \mathrm{S}\right)$ ", Contrib. Mineral. Petrol., vol. 88 , pp. 133-149, 1984.

[87] D. C. Gerlach, F. A. Frey, H. Moreno-Roa, and L. Lopez-Escobar, "Recent volcanism in the Puyehue-Cordon Caulle region, southern Andes, Chile $\left(40.5^{\circ} \mathrm{S}\right)$ : petrogenesis of evolved lavas", J. Petrol., vol. 29 , pp. 333-382, 1988 .

[88] R. Hickey-Vargas, H. Moreno Roa, L. Lopez Escobar, and F. A. Frey, "Geochemical variations in Andean basaltic and silicic lavas from the Villarrica-Lanin volcanic chain $\left(39.5^{\circ} \mathrm{S}\right)$ : an evaluation of source heterogeneity, fractional crystallization and crustal assimilation”, Contrib. Mineral. Petrol., vol. 103, pp. 361-386, 1989.

[89] L. López-Escobar, M. Tagiri, and M. Vergara, "Geochemical features of southern Andes Quaternary volcanics between $41^{\circ} 5^{\prime}$ and 4300'S”, Geol. Soc. Am, vol. Special Paper 265, pp. 45-56, 1991.

[90] L. López-Escobar, R. Kilian, P. D. Kempton, and M. Tagiri, "Petrography and geochemistry of Quaternary rocks from the southern volcanic zone of the Andes between $41^{\circ} 30^{\prime}$ and $46^{\circ} 00^{\prime} \mathrm{S}$, Chile", Rev. Geol. Chile, vol. 20, pp. 33-35, 1993.

[91] D. R. Tormey, R. Hickey-Vargas, F. A. Frey, and L. LópezEscobar, "Recent lavas from the Andean volcanic front (33 to $\left.42^{\circ} \mathrm{S}\right)$; interpretations of along-arc compositional variations", in Andean magmatism and its tectonic setting, Geol. Soc. Am., Special Paper, R. S. Harmon and C. W. Rapela, Eds. Boulder, Colorado, USA: Geol. Soc. Am., 1991, pp. 57-77.

[92] R. B. Trumbull, R. Wittenbrink, K. Hahne, R. Emmermann, W. Büsch, H. Gerstenberger, and W. Siebel, "Evidence for Late Miocene to Recent contamination of arc andesites by crustal melts in the Chilean Andes (25-26 $\mathrm{S})$ and its geodynamic implications", $J$. South. Am. Earth. Sci., vol. 12, pp. 135-155, 1999.

[93] M. Vergara, L. López-Escobar, A. Cancino, and B. Levi, "The Pichidangui formation; Some geochemical characteristics and tectonic implications of the Triassic marine volcanism in central Chile (31 ${ }^{\circ} 55^{\prime}$ to $32^{\circ} 20 '$ 'S)", Geol. Soc. Am., vol. Special Paper 265, pp. 93$98,1991$.

[94] B. Deruelle, "Petrology of the Plio-Quaternary volcanism of the south-central and meridional Andes", J. Volcanol. Geotherm. Res., vol. 14, pp. 77-124, 1982.

[95] S. L. de Silva, "Styles of zoning in central Andean ignimbrites: insights into magma chamber processes", Geol. Soc. Am. Special Paper, 265, pp. 217-232, 1991.

[96] J. A. Walker, T. N. Moulds, M. Zentilli, and M. D. Feigenson, "Spatial and temporal variatios in volcanics of the Andean Central volcanic zone (26 to $\left.28^{\circ} \mathrm{S}\right)$ ", Geol. Soc. Am., Special Paper 265, pp. 139-156, 1991.

[97] P. Sruoga, E. J. Llambías, L. Fauqué, D. Schonwandt, and D. G. Repol, "Volcanological and geochemical evolution of the Diamante caldera-Maipo volcano complex in the southern Andes of Argentina $\left(34^{\circ} 10^{\prime S}\right)$ ", J. South. Am. Earth. Sci., vol. 19, pp. 399-414, 2005 .
[98] S. M. Kay, V. Maksaev, R. Moscoso, C. Mpodozis, C. Nasi, and C. E. Gordillo, "Tertiary Andean magmatism in Chile and Argentina between $28^{\circ} \mathrm{S}$ and $33^{\circ} \mathrm{S}$ : correlation of magmatic chemistry with a changing Benioff zone", J. South. Am. Earth. Sci., vol. 1, pp. 2138,1988 .

[99] M. Vergara, L. López-Escobar, J. L. Palma, R. Hickey-Vargas, and C. Roeschmann, "Late Tertiary volcanic episodes in the area of the city of Santiago de Chile: new geochronological and geochemical data", J. South. Am. Earth. Sci., vol. 17, pp. 227-238, 2004.

[100] R. L. Hickey, F. A. Frey, D. C. Gerlach, and L. Lopez-Escobar, "Multiple sources for basaltic arc rocks from the southern volcanic zone of the Andes $\left(34^{\circ}-41^{\circ} \mathrm{S}\right)$ : trace element and isotopic evidence for contributions from subducted oceanic crust, mantle, and continental crust", J. Geophys. Res., vol. 91, pp. 5963-5983, 1986.

[101] M. L. Gorring, and S. M. Kay, "Mantle processes and sources of Neogene slab window magmas from southern Patagonia, Argentina," J. Petrol., vol. 42, pp. 1067-1094, 2001.

[102] M. D'Orazio, F. Innocenti, P. Manetti, M. J. Haller, G. Di Vincenzo, and S. Tonarini, "The late Piocene mafic lavas from the Camusú Aike volcanic field $\left(\sim 50^{\circ} \mathrm{S}\right.$, Argentina): evidence for geochemical variability in slab window magmatism", J. South. Am. Earth. Sci., vol. 18, pp. 107-124, 2005.

[103] G. I. Massaferro, M. J. Haller, M. D'Orazio, and V. I. Alric, "Subrecent volcanism in northern Patagonia: a tectonomagmatic approach", J. Volcanol. Geotherm. Res., vol. 155, pp. 227-243, 2006.

[104] S. Bruni, M. D'Orazio, M. J. Haller, F. Innocenti, P. Manetti, Z. Pécskay, and S. Tonarini, "Time-evolution of magma sources in a continental back-arc setting: the Cenozoic basalts from Sierra de San Bernardo (Patagonia, Chubut, Argentina)", Geol. Mag., vol. 145, pp. 714-732, 2008.

[105] M. J. Le Bas, R. W. Le Maitre, A. Streckeisen, and B. Zanettin, “A chemical classification of volcanic rocks based on the total alkalisilica diagram", J. Petrol., vol. 27, pp. 745-750, 1986.

[106] M. J. Le Bas, "IUGS reclassification of the high-Mg and picritic volcanic rocks", J. Petrol., vol. 41, pp. 1467-1470, 2000.

[107] S. P. Verma, I. S. Torres-Alvarado, Z. T. Sotelo-Rodríguez, "SINCLAS: standard igneous norm and volcanic rock classification system", Comput. Geosci., vol. 28, pp. 711-715, 2002.

[108] S. P. Verma, I. S. Torres-Alvarado, and F. Velasco-Tapia, "A revised CIPW norm", Schweiz. Miner. Petrog. Mitteil., vol. 83, pp. 197-216, 2003

[109] E. A. K. Middlemost, "Iron oxidation ratios, norms and the classification of volcanic rocks", Chem. Geol., vol. 77, pp. 19-26, 1989.

[110] J. A. Pearce, and G. H. Gale, "Identification of ore-deposition environment from trace-element geochemistry of associated igneous host rocks", Geol. Soc. London Spec. Publ., pp. 14-24, 1979.

[111] J. A. Pearce, and M. J. Norry, "Petrogenetic implications of Ti, Zr, $\mathrm{Y}$, and $\mathrm{Nb}$ variations in volcanic rocks," Contrib. Mineral. Petrol., vol. 69 , pp. 33-47, 1979.

[112] J. W. Shervais, "Ti-V plots and the petrogenesis of modern and ophiolitic lavas”, Earth Planet. Sci. Lett., vol. 59, pp. 101-118, 1982.

[113] J. A. Pearce, N. B. W. Harris, and A. G. Tindle, "Trace element discrimination diagrams for the tectonic interpretation of granitic rocks", J. Petrol., vol. 25, pp. 956-983, 1984.

[114] J. C. Butler, and A. Woronow, "Discrimination among tectonic settings using trace element abundances of basalts", J. Geophys. Res., vol. 91, pp. 10289-10300, 1986.

[115] M. Vasconcelos-F., S. P. Verma, and J. F. Rodríguez-G., "Discriminación tectónica: nuevo diagrama $\mathrm{Nb}$-Ba para arcos continentales, arcos insulares, "rifts" e islas oceánicas en rocas máficas", Bol. Soc. Esp. Min., vol. 21, pp. 129-146, 1998.

[116] M. Vasconcelos-F., S. P. Verma, and R. C. Vargas-B., "Diagrama Ti-V: una nueva propuesta de discriminación para magmas básicos en cinco ambientes tectónicos", Rev. Mex. Cienc. Geol., vol. 18, pp. 162-174, 2001

[117] S. P. Verma, "Statistical evaluation of bivariate, ternary and discriminant function tectonomagmatic discrimination diagrams", Turk. J. Earth Sci., 2009, in press.

[118] J. A. Pearce, and J. R. Cann, "Tectonic setting of basic volcanic rocks determined using trace element analyses," Earth Planet. Sci. Lett., vol. 19, pp. 290-300, 1973.

[119] B. Cabanis, and M. Lecolle, "Le diagramme La/10-Y/15-Nb/8: un outil pour la discrimination des séries volcaniques et la mise en évidence des processus de mélange et/ou de contamination crustale", C.R. Acad. Sci. Paris, vol. 309, pp. 2023-2029, 1989. 
[120] D. A. Wood, J.-L. Joron, and M. Treuil, "Are-appraisal of the use of trace elements to classify and discriminate between magma series erupted in different tectonic settings", Earth Planet. Sci. Lett., vol. 45 , pp. 326-336, 1979.

[121] D. A. Wood, "The application of a Th-Hf-Ta diagram to problems of tectonomagmatic classification and to establishing the nature of crustal contamination of basaltic lavas of the British Tertiary volcanic province", Earth Planet. Sci. Lett., vol. 50, pp. 11-30, 1980.

[122] J. C. Butler, "Trends in ternary petrologic variation diagrams - fact or fantasy?" Am. Mineral., vol. 64, pp. 1115-1121, 1979.

[123] G. S. Watson, and H. Nguyen, "A confidence region in a ternary diagram from point counts", Math. Geol., vol. 17, pp. 209-213, 1985.

[124] F. Medak, and N. Cressie, "Confidence regions in ternary diagrams based on the power-divergence statistics", Math. Geol., vol. 23, pp. 1045-1057, 1991.

[125] S. Agrawal, M. Guevara, and S. P. Verma, "Discriminant analysis applied to establish major-element field boundaries for tectonic varieties of basic rocks", Int. Geol. Rev., vol. 46, pp. 575-594, 2004.

[126] S. P. Verma, M. Guevara, and S. Agrawal, "Discriminating four tectonic settings: five new geochemical diagrams for basic and ultrabasic volcanic rocks based on log-ratio transformation of major-element data", J. Earth Syst. Sci., vol. 115, pp. 485-528,

[127] S006grawal, and S. P. Verma, "Comment on "Tectonic classification of basalts with classification trees" by Pieter Vermeesch (2006)", Geochim. Cosmochim. Acta, vol. 71, pp. 3388-3390, 2007.

[128] S. Agrawal, S. P. Verma, and M. Guevara, "Tectonic discrimination of basic and ultrabasic volcanic rocks through log-transformed ratios of immobile trace elements", Int. Geol. Rev., vol. 50, pp. 1057-1079, 2008.

[129] F. Chayes, "On correlation between variables of constant sum", $J$. Geophys. Res., vol. 65, pp. 4185-4193, 1960.

[130] F. Chayes, "Ratio correlation. A manual for students of petrology and geochemistry", Chicago and London: The University of Chicago Press, 1978, p. 99.

[131] J. Aitchison, "The statistical analysis of compositional data", London New York: Chapman and Hall, p. 416, 1986.

[132] A. Woronow, "Power and robustness of Aitchison's test for complete subcompositional independence in closed arrays", Math. Geol., vol. 18, 1986, pp. 563-575.

[133] J. Aitchison, "Logratios and natural laws in compositional data analysis", Math. Geol., vol. 31, pp. 563-580, 1999.

[134] S. Agrawal, "Geochemical discrimination diagrams: a simple way of replacing eye-fitted boundaries with probability based classifier surfaces", J. Geol. Soc. India, vol. 54, pp. 335-346, 1999.

[135] J. Aitchison, and J. J. Egozcue, "Compositional data analysis: where are we and where should we be heading?," Math. Geol., vol. 37, pp. 829-850, 2005.

[136] H. C. Sheth, "Do major oxide tectonic discrimination diagrams work? Evaluating new log-ratio and discriminant-analysis-based diagrams with Indian Ocean mafic volcanics and Asian ophiolites"”, Terra Nova, vol. 20, pp. 229-236, 2008.

[137] N. M. S. Rock, "The need for standarization of normalized multielement diagrams in geochemistry: a comment", Geochem. J., vol. 21, pp. 75-84, 1987

[138] N. Nakamura, "Determination of REE, Ba, Mg, $\mathrm{Na}$ and $\mathrm{K}$ in carbonaceous and ordinary chondrites", Geochim. Cosmochim. Acta, vol. 38 , pp. 757-775, 1974

[139] L. A. Haskin, M. A. Haskin, F. A. Frey, and T. R. Wildeman,'Relative and absolute terrestrial abundances of the rare earths", in Origin and distribution of the elements, L. H. Ahrens, Ed., Oxford, Pergamon Press, 1968, pp. 889-912.

[140] W. F. McDonough, and S.-S. Sun, "The composition of the Earth", Chem. Geol., vol. 120, pp. 223-253, 1995.

[141] J. A. Pearce,'Trace element characteristics of lavas from destructive plate boundaries", in Andesites, R. S. Thorpe, Ed., Chichester, John Wiley \& Sons, 1982, pp. 525-548.

[142] S-S. Sun, and W. F. McDonough, "Chemical and isotopic systematics of oceanic basalts: implications for mantle composition and processes", in Magmatism in the ocean basins, A. D. Saunders and M. J. Norry, Eds. London and Oxford, UK: Geol. Soc. Spec. Publ., 1989, pp. 313-345.

[143] H. R. Rollinson, "Using geochemical data: evaluation, presentation, interpretation". Essex: Longman Scientific Technical, 1993, pp. 344
[144] J. L. Jensen, L. W. Lake, P. W. M. Corbett, and D. J. Goggin, "Statistics for petroleum engineers and geoscientists", Upper Saddle River: Prentice-Hall, 1997, pp. 390.

[145] P. R. Bevington, and D. K. Robinson, "Data reduction and error analysis for the physical sciences”, Boston: Mc Graw Hill, 2003, p. 320 .

[146] S. P. Verma, "Estadística básica para el manejo de datos experimentales: aplicación en la Geoquímica" (Geoquimiometría). México, D.F., UNAM, 2005, pp. 186.

[147] S. P. Verma, "Evaluation of polynomial regression models for the Student $\mathrm{t}$ and Fisher $\mathrm{F}$ critical values, the best interpolation equations from double and triple natural logarithm transformation of degrees of freedom up to 1000 , and their applications to quality control in science and engineering", Rev. Mex. Cienc. Geol., vol. 26, pp. 79-92, 2009.

[148] S. P. Verma, "Sixteen statistical tests for outlier detection and rejection in evaluation of International Geochemical Reference Materials: example of microgabbro PM-S", Geostandards Newsletter. J Geostand Geoanal, vol. 21, pp. 59-75, 1997.

[149] V. Barnett, and T. Lewis, "Outliers in statistical data". Chichester: John Wiley \& Sons, 1994, pp. 584.

[150] S. P. Verma, and A. Quiroz-Ruiz, "Critical values for six Dixon tests for outliers in normal samples up to sizes 100, and applications in science and engineering," Rev. Mex. Cienc. Geol., vol. 23, pp. 133-161, 2006

[151] S. P. Verma, and A. Quiroz-Ruiz, "Critical values for 22 discordancy test variants for outliers in normal samples up to sizes 100 , and applications in science and engineering", Rev. Mex. Cienc. Geol., vol. 23, pp. 302-319, 2006.

[152] S. P. Verma, A. Quiroz-Ruiz, and L. Díaz-González, "Critical values for 33 discordancy test variants for outliers in normal samples up to sizes 1000, and applications in quality control in Earth Sciences", Rev. Mex. Cienc. Geol., vol. 25, pp. 82-96, 2008.

[153] S. P. Verma, and A. Quiroz-Ruiz, "Critical values for 33 discordancy test variants for outliers in normal samples for very large sizes of 1,000 to 30,000", Rev. Mex. Cienc. Geol., vol. 25, pp. 369381, 2008.

[154] S. P. Verma, and L. Díaz-González, "DODESYS: Discordant Outlier Detection and Elimination System and its application to quality control in science and engineering", Accred. Qual. Assur., 2009, submitted

[155] S. P. Verma, L. Díaz-González, and R. González-Ramírez, "Relative efficiency of single-outlier discordancy tests for processing geochemical data on reference materials", Geostand. Geoanal. Res., vol. 33, pp. 29-49, 2009.

[156] S. P. Verma, I. S. Torres-Alvarado, M. Satir, and P. F. Dobson, "Hydrothermal alteration effects in geochemistry and $\mathrm{Sr}, \mathrm{Nd}, \mathrm{Pb}$, and $\mathrm{O}$ isotopes of magmas from the Los Azufres geothermal field (Mexico): a statistical approach", Geochem. J., vol. 39, pp. 141163, 2005.

[157] K. Pandarinath, P. Dulski, I. S. Torres-Alvarado, S. P. Verma, "Element mobility during hydrothermal alteration of rhyolitic rocks of the Los Azufres geothermal field, Mexico", Geothermics, vol 37, pp. 53-72, 2008.

[158] K. Pandarinath, "Clay minerals in SW Indian continental shelf sediment cores as indicators of provenance and palaeomonsoonal conditions: a statistical approach", Int. Geol. Rev., vol. 51, pp. 145 165,2009

[159] R. González-Ramírez, L. Díaz-González, and S. P. Verma, "Eficiencia relativa de las 33 pruebas de discordancia para valores desviados basada en datos geoquímicos de materiales de referncia", Rev. Mex. Cienc. Geol., vol. 26, 2009, in press.

[160] S. P. Verma, "Seawater alteration effects on REE, K, Rb, Cs, Sr, U, $\mathrm{Th}, \mathrm{Pb}$ and $\mathrm{Sr}-\mathrm{Nd}-\mathrm{Pb}$ isotope systematics of Mid-Ocean Ridge Basalt", Geochem. J., vol. 26, pp. 159-177, 1992.

[161] R. von Huene, "The Middle America convergent plate boundary, Guatemala", in The Eastern Pacific Ocean and Hawaii, E. L. Winterer, D. M. Hussong and R. W. Decker, Eds. Boulder, Colorado, USA, Geol. Soc. Am., pp. 535-550, 1989.

[162] P. Molnar, and L. R. Sykes, "Tectonics of the Caribbean and Middle America regions from focal mechanisms and seismicity", Geol. Soc. Am. Bull., vol. 80, pp. 1639-1684, 1969.

[163] V. H. Aguilar-Y-Vargas, and S. P. Verma, "Composición química (elementos mayores) de los magmas en el Cinturón Volcánico Mexicano", Geofis. Int., vol. 26, pp. 195-272, 1987. 
[164] I. S. Torres-Alvarado, S. P. Verma, and F. Velasco-Tapia, "Comment to "Generation of oceanic-island basalt type volcanism in the western Trans-Mexican volcanic belt by slab rollback, asthenosphere infiltration, and variable flux melting", Geology, vol. 30, pp. 857-858, 2002.

[165] J. F. W. Negendank, R. Emmermann, F. Mooser, U. Seifert-Kraus, and H. J. Tobschall, "Evolution of some Tertiary and Quaternary central volcanoes of the Trans-Mexican Volcanic Belt and possible different positions of the Benioff zone", Zentralb. Geol. Paläontol., vol. 3/4, pp. 183-194, 1981 .

[166] J. F. Luhr, S. A. Nelson, J. F. Allan, and I. S. E. Carmichael, “Active rifting in southwestern Mexico: Manifestations of an incipient eastward spreading-ridge jump", Geology, vol. 13, pp. 54-57, 1985.

[167] J. F. Allan, "Geology of the northern Colima and Zacoalco grabens, southwest Mexico: Late Cenozoic rifting in the Mexican Volcanic Belt”, Geol. Soc. Am. Bull., vol. 97, pp. 473-485, 1986.

[168] V. H. Garduño-Monroy, J. Spinner, and E. Ceragioli, "Geological and structural study of the Chapala rift, State of Jalisco, Mexico", Geofis. Int., vol. 32, pp. 487-499, 1993.

[169] H. M. Frey, R. A. Lange, C. M. Hall, H. Delgado-Granados, and I. S. E. Carmichael, "A Pliocene ignimbrite flare-up along the TepicZacoalco rift: evidence for the initial stages of rifting between the Jalisco block (Mexico) and North America", Geol. Soc. Am. Bull., vol. 119, pp. 49-64, 2007.

[170] C. A. Johnson, and C. G. A. Harrison, "Neotectonics in central Mexico," Phys. Earth Planet. Int., vol. 64, pp. 187-210, 1990.

[171] M. Suter, O. Quintero-Legorreta, M. López-Martínez, G. AguirreDíaz, and E. Farrar, "The Acambay graben: active intraarc extension in the Trans-Mexican Volcanic Belt, Mexico", Tectonics, vol. 14, pp. 1245-1262, 1995.

[172] M. Suter, M. C. Martínez, M. L. Martínez, and E. Farrar, "The Aljibes half-graben - active extension at the boundary between the Trans-Mexican Volcanic Belt and the basin and range province, Mexico", Geol. Soc. Am. Bull., vol. 107, pp. 627-641, 1995.

[173] J. F. W. Negendank, R. Emmermann, R. Krawczyk, F. Mooser, H. Tobschall, and D. Werle, "Geological and geochemical investigations on the eastern Trans Mexican Volcanic Belt", Geofis. Int., vol. 24, pp. 477-575, 1985.

[174] L. Ferrari, G. Pasquare, and A. Tibaldi, "Plio-Quaternary tectonics of the central Mexican Volcanic Belt and some constraints on its rifting mode", Geofis. Int., vol. 29, pp. 5-18, 1990.

[175] S. A. Alaniz-Alvarez, A. F. Nieto-Samaniego, and L. Ferrari, "Effect of strain rate in the distribution of monogenetic and polygenetic volcanism in the TransMexican Volcanic Belt", Geology, vol. 26, pp. 591-594, 1998.

[176] F. Anguita, S.P. Verma, A. Márquez, M. Vasconcelos-F, I. López, and A. Laurrieta, "Circular features in the Trans-Mexican Volcanic Belt”, J. Volcanol. Geotherm. Res., vol. 107, pp. 265-274, 2001.

[177] P. Wassmer, D. Geissert, N. de Fraipont, E. Enríquez-Fernandez, "Morphological evolution of La Concepción valley by huge mass movements on plateau edges in the eastern part of the Mexican Volcanic Belt (Xalapa, Veracruz, Mexico)", Acta Volcanol., vol. 16, pp. 125-132, 2004

[178] F. Mooser, A. Montiel, and A. Zuñiga, "Nuevo mapa geológico de las cuencas de México, Toluca y Puebla. Estratigrafía, tectónica y aspectos geotérmicos", México, Comisión Federal de Electicidad, 1996.

[179] M. Suter, M. L. Martínez, O. Q. Legorreta, and M. Carrillo Martínez, "Quaternary intra-arc extension in the central TransMexican volcanic belt", Geol. Soc. Am. Bull., vol. 113, pp. 693703, 2001.

[180] D. J. Morán-Zenteno, M. Cerca, and J. D. Keppie, "The Cenozoic tectonic and magmatic evolution of southwestern México: advances and problems of interpretation", in Geology of Mexico: celebrating the centenary of the Geological Society of Mexico, S. A. Alaniz-Álvarez, A. F. Nieto-Samaniego, Eds. Boulder, Colorado, USA: Geological Society of America, 2007, pp. 71-91.

[181] S. A. Alaniz-Álvarez, and A. F. Nieto-Samaniego, "The Taxco-San Miguel de Allende fault system and the Trans-Mexican Volcanic Belt: two tectonic boundaries in central México active during the Cenozoic", in Geology of Mexico: celebrating the centenary of the Geological Society of Mexico, S. A. Alaniz-Álvarez, A. F. NietoSamaniego, Eds., Boulder, Colorado, USA: Geological Society of America, 2007, pp. 301-316.

[182] S. P. Verma, and V. H. Aguilar-Y-Vargas, "Bulk chemical composition of magmas in the Mexican Volcanic Belt (Mexico) and inap- plicability of generalized arc-models", Chem. Erde, vol. 48, pp 203-221, 1988.

[183] S. P. Verma, and T. Hasenaka, "Sr, Nd, and Pb isotopic and trace element geochemical contraints for a veined-mantle source of magmas in the Michoacán-Guanajuato volcanic field, west-central Mexican Volcanic Belt", Geochem. J., vol. 38, pp. 43-65, 2004.

[184] F. Velasco-Tapia, and S. P. Verma, "Estado actual de la investigación geoquímica en el campo monogenético de la Sierra de Chichinautzin: análisis de información y perspectivas", Rev. Mex. Cienc. Geol., vol. 18, pp. 1-36, 2001.

[185] H. C. Sheth, I. S. Torres-Alvarado, and S. P. Verma, "What is the "calc-alkaline rock series"?", Int. Geol. Rev., vol. 44, pp. 686-701, 2002.

[186] S. P. Verma, and J. F. Luhr, "Sr, Nd, and Pb isotopic evidence for the origin and evolution of the Cántaro-Colima volcanic chain, western Mexican Volcanic Belt", J. Volcanol. Geotherm. Res., under review, 2009.

[187] G.T. Nixon, "Petrology of younger andesites and dacites of Iztaccíhuatl volcano, Mexico: I. Disequilibrium phenocryst assemblages as indicators of magma chamber processes", J. Petrol., vol. 29, pp. 213-26, 1988.

[188] F. Velasco Tapia, "Aspectos Geoestadísticos en Geoquímica Analítica: Aplicación en el Modelado Geoquímico e Isotópico de la Sierra de Chichinautzin, Cinturón Volcánico Mexicano”, Doctoral thesis, Posgrado en Ciencias de la Tierra, Universidad Nacional Autónoma de México, 2001

[189] B. J. Witter, C. V. Kress, C. G. Newhall, C. G., "Volcan Popocatepetl, Mexico. Petrology, magma mixing, and immediate sources of volatiles for the 1994-Present eruptions", J. Petrol., vol. 46, pp. 2337-2366, 2005.

[190] G. J. Aguirre-Díaz, "Recurrent magma mingling in successive ignimbrites from Amealco caldera, central Mexico", Bull. Volcanol., vol. 63, pp. 238-251, 2001

[191] A. Márquez, and C. De Ignacio, "Mineralogical and geochemical constraints for the origin and evolution of magmas in Sierra Chichinautzin, Central Mexican Volcanic Belt", Lithos, vol. 62, pp. 35-62, 2002.

[192] P. Cervantes, and P. J. Wallace, "Role of $\mathrm{H}_{2} \mathrm{O}$ in subduction-zone magmatism: new insights from melt inclusions in high-Mg basalts from central Mexico", Geology, vol. 31, pp. 235-238, 2003.

[193] A. W. Hofmann, and M. D. Feigenson, "Case studies on the origin of basalt. I. Theory and reassessment of Grenada basalts", Contrib. Mineral. Petrol., vol. 84, pp. 382-389, 1983.

[194] A. W. Hofmann, M. D. Feigenson, and I. Raczek, "Case studies on the origen of basalt: III. Petrogenesis of the Mauna Ulu eruption, Kilauea, 1969-1971", Contrib. Mineral. Petrol., vol. 88, pp. 24-35, 1984.

[195] D. McKenzie, and R. K. O'Nions, "Partial melt distributions from inversion of rare earth element concentrations", J. Petrol., vol. 32, pp. 1021-1091, 1991.

[196] D. S. Ormerod, N. W. Rogers, and C. J. Hawkesworth, "Melting in the lithospheric mantle: inverse modelling of alkali-olivine basalts from the Big Pine volcanic field, California", Contrib. Mineral. Petrol., vol. 108, pp. 305-317, 1991.

[197] M. D. Feigenson, and M. J. Carr, "The source of Central American lavas: inferences from geochemical inverse modeling", Contrib. Mineral. Petrol., vol. 113, pp. 226-235, 1993.

[198] M. D. Feigenson, L. L. Bolge, M. J. Carr, and C. T. Herzberg, "REE, inverse modeling of HSDP2 basalts: Evidence for multiple source in the Hawaiian plume", Geochem. Geophys. Geosys., vol. 4, pp. 1-25, 2003.

[199] M. D. Feigenson, L. L. Bolge, M. J. Carr, and C. T. Herzberg, "REE, inverse modeling of HSDP2 basalts: Evidence for multiple source in the Hawaiian plume", Geochem. Geophys. Geosys., vol. 4, pp. 1-25, 2003.

[200] S. A. Nelson, E. Gonzalez-Caver, and T. K. Kyser, "Constraints on the origin of alkaline and calc-alkaline magmas from the Tuxtla Volcanic Field, Veracruz, Mexico", Contrib. Mineral. Petrol., vol. 122, pp. 191-211, 1995.

[201] S. P. Verma, A. Salazar-V., J. F. W. Negendank, M. Milan, I. Navarro-L, and T. Besch, "Características petrográficas y geoquímicas de elementos mayores del Campo Volcánico de Los Tuxtlas, Veracruz, México", Geofis. Int., vol. 32, pp. 237-248, 1993.

[202] A. R. McBirney, Igneous Petrology. 3rd ed, New York: Jones and Bartlett Publishers, 2007, pp. 550. 
[203] G. Faure, Origin of the Igneous Rocks. The Isotopic Evidence. Berlin: Springer, 2001, p. 496.

[204] M. G. Best, and E. H. Christiansen, Igneous Petrology. New York, Wiley-Blackwell, 2001, p. 455.

[205] S. P. Verma, and M. P. Verma, "A compilation of $\mathrm{Sr}$ and $\mathrm{Nd}$ isotope data on Mexico", J. Geol. Soc. India, vol. 27, pp. 130-143, 1986.

[206] I. S. Torres-Alvarado, S. P. Verma, and G. Carrasco-Núñez, "Compilation of radiogenic isotope data in Mexico and their petrogenetic implications", Proc. Indian Acad. Sci. (Earth Planet. Sci.), vol. 109 , pp. $67-78,2000$.

[207] A. Gómez-Tuena, A. B. LaGatta, C. H. Langmuir, S. L. Goldstein, F. Ortega-Gutiérrez, and G. Carrasco-Núñez, "Temporal control of subduction magmatism in the eastern Trans-Mexican Volcanic Belt: Mantle sources, slab contributions, and crustal contamination", Geochem. Geophys. Geosyst., vol. 4, 8912, 2003.

[208] J. C. Lassiter, and J. F. Luhr, "Osmium abundance and isotopic variations in mafic Mexican volcanic rocks: evidence for crustal contamination and constraints on the geochemical behavior of osmium during partial melting and fractional crystallization", Geochem. Geophys. Geosyst., vol. 2, 2000GC000116, 2001.

[209] J. Chesley, J. Ruiz, K. Righter, L. Ferrari, and A. Gómez-Tuena, "Source contamination versus assimilation: an example from the Trans-Mexican Volcanic Arc", Earth Planet. Sci. Lett., vol. 195, pp. 211-221, 2002.

[210] F. Tera, L. Brown, J. Morris, I. S. Sacks, J. Klein, and R. Middleton, "Sediment incorporation in island-arc magmas: inferences from ${ }^{10} \mathrm{Be} "$, Geochim. Cosmochim. Acta, vol. 50, pp. 535-550, 1986.

[211] X. Pérez-Campos, Y. H. Kim, A. Husker, P. M. Davis, R. W. Clayton, A. Iglesias, J. F. Pacheco, S. K. Singh, V. C. Manea, and M. Gurnis, "Horizontal subduction and truncation of the Cocos plate beneath central Mexico", Geophys. Res. Lett., vol. 35, pp. L18303, 2008.

[212] UNAM and CENAPRED Seismology Group, "The Milpa Alta earthquake of January 21, 1995”, Geofis. Int., vol. 34, pp. 355-362, 1995.

[213] S. K. Singh, and M. Pardo, "Geometry of the Benioff zone and state of stress in the overriding plate in central Mexico", Geophys. Res. Lett., vol. 20, pp. 1483-1486, 1993.

[214] G. Suarez, and S. K. Singh, "Tectonic interpretation of the TransMexican Volcanic Belt—discussion”, Tectonophysics, vol. 127, pp. 155-160, 1986.

[215] F. Ego, and V. Ansan, "Why is the central Trans-Mexican volcanic belt $\left(102^{\circ}-99^{\circ} \mathrm{W}\right)$ in transtensive deformation?", Tectonophysics, vol. 359, pp. 189-208, 2002.

[216] M. Pardo, and G. Suárez, "Shape of the subducted Rivera and Cocos plates in southern Mexico: Seismic and tectonic implications", J. Geophys. Res., vol. 100, pp. 12,357-12,373, 1995.

[217] S. K. Singh, L. Ponce, and S. P. Nishenko, "The great Jalisco, Mexico earthquakes of 1932: Subduction of the Rivera plate", Bull. Seismol. Soc. Am., vol. 75, pp. 1301-1313, 1985.

[218] M. Pardo, and G. Suárez, "Steep subduction geometry of the Rivera late beneath the Jalisco block in western Mexico", J. Geophys. Res., vol. 20, pp. 2391-2394, 1993.

[219] C. DeMets, and S. Stein, "Present-day kinematics of the Rivera plate and implications for tectonics in southwestern Mexico", $J$. Geophys. Res., vol. 95, pp. 21931-21948, 1990.

[220] C. DeMets, and D. S. Wilson, "Relative motions of the Pacific, Rivera, North American, and Cocos plates", J. Geophys. Res., vol. 102, pp. 2789-2806, 1997.

[221] T. Yang, S. P. Grand, D. Wilson, M. Guzmán-Speziale, J. M. Gómez-González, T. Dominguez-Reyes, and J. Ni, "Seismic structure beneath the Rivera subduction zone from finite-frequency seismic tomography", J. Geophys. Res. - Solid Earth, vol. 114, Art. No. B01302, 2009.
[222] A. Jording, L. Ferrari, J. Arzate, H. Jödicke, "Crustal variations and terrane boundaries in southern Mexico as imaged by magnetotelluric transfer functions", Tectonophysics, vol. 327, pp. 1-13, 2000.

[223] J. O. Campos-Enríquez, and O. Sánchez-Zamora, "Crustal structure across southern Mexico inferred from gravity data", J. South. Am. Earth. Sci., vol. 13, pp. 479-489, 2000.

[224] J. O. Campos-Enríquez, F. Domínguez-Méndez, M. LozadaZumaets, H. F. Morales-Rodríguez, and J. A. AndaverdeArredondo, "Application of the Gauss theorem to the study of silicic calderas: the calders of La Primavera, Los Azufres, and Los Humeros (Mexico)", J. Volcanol. Geotherm. Res., vol. 147, pp. 3967, 2005.

[225] F. Ortega-Gutierrez, M. Elias-Herrera, and M. G. DavalosElizondo, "On the nature and role of the lower crust in the volcanic front of the Trans-Mexican Volcanic Belt and its fore-arc region, southern and central Mexico", Rev. Mex. Cienc. Geol., vol. 25, pp. 346-364, 2008.

[226] A. R. McBirney, H. P. Taylor, and R. L. Armstrong, "Paricutin reexamined: a classical example of crustal assimilation in calcalkaline magma", Contrib. Mineral. Petrol., vol. 95, pp. 4-20, 1987.

[227] T. Besch, S. P. Verma, U. Kramm, J. F. W. Negendank, H. J. Tobschall, and R. Emmermann, "Assimilation of sialic crustal material by volcanics of the easternmost extension of the TransMexican Volcanic Belt: Evidence from $\mathrm{Sr}$ and $\mathrm{Nd}$ isotopes", Geofis. Int., vol. 34, pp. 263-282, 1995.

[228] S. P. Verma, and J. Andaverde, "Coupling of thermal and chemical simulations in a 3-D integrated magma chamber-reservoir model: A new geothermal energy research frontier", in Geothermal Energy Research Trends, H. I. Ueckermann, Ed., New York: Nova Science Publishers, Chapter 7, 2007, pp. 149-188.

[229] A. Gómez-Tuena, M. T. Orozco-Esquivel, and L. Ferrari, "Igneous petrogenesis of the Trans-Mexican Volcanic belt", in Geology of Mexico: celebrating the centenary of the Geological Society of Mexico, S. A. Alaniz-Álvarez, A. F. Nieto-Samaniego, Eds.: Geol. Soc. Am., 2007, pp. 129-181.

[230] M. J. Defant, T. E. Jackson, M. S. Drummond, J. Z. De Boer, H. Bellon, M. D. Feigenson, R. C. Maury, and R. H. Stewart, "The geochemistry of young volcanism throughout western Panama and southeastern Costa Rica: an overview", J. Geol. Soc. London, vol. 149, pp. 569-579, 1992.

[231] D. L. Harry, and N. L. Green, "Slab dehydration and basalt petrogenesis in subduction systems involving very young oceanic lithosphere", Chem. Geol., vol. 160, pp. 309-333, 1999.

[232] S. T. Johnston, and D. J. Thorkelson, "Cocos-Nazca slab window Beneath Central America", Earth. Planet. Sci. Lett., vol. 146, pp. 465-474, 1997.

[233] M. D. Feigenson, M. J. Carr, S. V. Maharaj, S. Juliano, and L. L. Bolge, "Lead isotope composition of Central American volcanoes: influence of the Galapagos plume", Geochem. Geophys. Geosys., vol. 5, 2004.

[234] R. M. Russo, and P. G. Silver, "Trench parallel flow beneath the Nazca plate from seismic anisotropy", Science, vol. 263, pp. 1105$1111,1994$.

[235] E. A. Herrstrom, M. K. Reagan, and J. D. Morris, "Variations in lava composition associated with flow of asthenosphere beneath southern Central America", Geology, vol. 23, pp. 617-620, 1995.

[236] M. Abratis, and G. Wörner, "Ridge collision, slab-window formation, and the flux of Pacific asthenosphere into the Caribbean realm", Geology, vol. 29, pp. 127-130, 2001.

[237] E. Gazel, M. J. Carr, K. Hoernle, M. D. Feigenson, D. Szymanski, F. Hauff, and P. van den Bogaard, "Galapagos-OIB signature in southern Central America: mantle refertilization by arc-hot spot interaction", Geochem, Geophy, Geosys., vol. 10, Q02S11, 2009. 